\title{
Analysis of the ftz upstream element: germ layer-specific enhancers are independently autoregulated
}

\author{
Leslie Pick, ${ }^{1}$ Alexander Schier, Markus Affolter, Thomas Schmidt-Glenewinkel, ${ }^{2}$ and Walter J. \\ Gehring \\ Department of Cell Biology, Biozentrum, University of Basel, CH-4056 Basel, Switzerland; ${ }^{2}$ Department of Biological \\ Sciences, Hunter College, City University of New York, New York 10021 USA
}

\begin{abstract}
The Drosophila fushi tarazu (ftz) upstream element is an enhancer-like element that is required for the correct expression of $f t z$ in developing embryos and that directs transcription from a minimal promoter in a ftz-like seven-striped pattern. Using a deletion analysis, we have identified several independent cis-regulatory elements in the upstream element. A distal enhancer directs fusion gene expression in seven stripes primarily in the mesoderm. A more complex proximal enhancer contains a mesodermally active element and a second element with which it interacts to generate seven stripes in the ectoderm. Striped expression directed by each enhancer is $f t z$-dependent, and each contains binding sites for purified $f t z$ homeo domain. We suggest that $f t z$ protein acts in combination with germ layer-restricted transcription factors directly and positively to regulate the transcription of its own gene.
\end{abstract}

[Key Words: Drosophila; enhancer; autoregulation; fushi tarazu gene; transcriptional control]

Received February 12, 1990; revised version accepted April 20, 1990.

The development of a complex organism from a fertilized egg requires the differential expression of genetic information in a temporally and spatially restricted fashion. This differential expression is frequently regulated at the level of transcription initiation (for reviews, see Maniatis et al. 1987; Mitchell and Tjian 1989). In such cases, cis-acting DNA sequences mediate interactions between trans-acting protein factors and RNA polymerase II or the "general transcription machinery" to activate transcription. Promoter elements, located close to the transcription start site, are required for efficient initiation and positioning of the start site, whereas upstream regulatory elements or enhancers act to increase the rate of transcription from a given promoter. Enhancers are characterized by their abilities to (1) stimulate transcription over large and varying distances, (2) act in an orientation-independent fashion, and (3) stimulate transcription of heterologous promoters (Serfling et al. 1985). For both viral and cellular genes, discrete cisacting regulatory elements have been identified that direct transcription in a cell type-restricted fashion. Although some cell type-specific enhancers have been studied in detail (Atchison 1988), only a small number have been examined in their native cellular environments in transgenic animals (Posakony et al. 1985; Garabedian et al. 1986; Hammer et al. 1987; Pinkert et al.

${ }^{1}$ Present address: Brookdale Center for Molecular Biology, Mount Sinai School of Medicine, New York, New York 10029-6574 USA.
1987; Johnson et al. 1989; Logan et al. 1989). Much of what we know about enhancer function comes from studies of viral model systems. Analysis of the wellcharacterized viral SV40 enhancers suggests that the basic building blocks of enhancers are short "enhansons" that correspond to the binding sites for transacting factors (Ondek et al. 1988). Different enhancer motifs may be active in different cell types, suggesting that the availability of cell type-specific transcription factors may control the specificity of enhancer activation (Schirm et al. 1987). Given the complexity of promoter and enhancer elements, it is possible to construct a scenario in which transcriptional specificity is determined by the combinatorial action of general and/or specific trans-acting factors that interact with the same, overlapping, or unique sets of regulatory sequences. This type of model may be particularly informative when applied to developmentally regulated gene expression.

Developmental and genetic studies of Drosophila melanogaster have led to the identification of groups of genes that are required to establish the basic body plan of the fly. These genes include the maternally active coordinate genes and the zygotically active segmentation and homeotic genes (Lewis 1978; Nüsslein-Volhard and Wieschavs 1980; Nüsslein-Volhard et al. 1987). These genes are expressed in spatially and temporally restricted patterns that are frequently dynamic and rapidly evolving. For example, in the case of the segmentation gene fushi tarazu (ftz), transcripts are first detected 
throughout the embryo at low levels during nuclear cycle 10 and accumulate to higher levels in a broad band between 15 and $65 \%$ egg length by cycle 12 . As cellularization begins (early cycle 14), gaps appear in this broad band, generating transiently four and, then, seven stripes that encircle the blastoderm embryo (late cycle 14). At gastrulation and early germ-band extension, $f t z$ transcripts are detected in seven stripes in the primordia of the even-numbered parasegments (PS 2-14) in both the ectoderm and underlying mesoderm (Hafen et al. 1984; Martinez-Arias and Lawrence 1985; Weir and Kornberg 1985). Later, $f t z$ is also expressed in a subset of cells in the developing central nervous system and hindgut /Carroll and Scott 1985; Hiromi et al. 1985; Krause et al. 1988).

Analysis of the expression patterns of a number of segmentation and homeotic genes (for review and discussion, see Levine and Wedeen 1985; Gergen et al. 1986; Scott and O'Farrell 1986; Akam 1987; Lawrence 1987; Ingham 1988) and the deleterious effects resulting from their ectopic expression (Struhl 1985; Ish-Horowicz and Pinchin 1987; Schneuwly et al. 1987) suggest that these genes must be expressed in particular domains in time and space to ensure the correct development of the embryo. Thus, understanding how these expression patterns are controlled is essential for understanding embryonic development. The expression patterns of many developmentally regulated genes appear to be controlled primarily at the level of transcription initiation, frequently in response to transcriptional control regions that act over very large distances (Hiromi et al. 1985; Peifer et al. 1987; Bienz et al. 1988; Boulet and Scott 1988; Howard et al. 1988; Goto et al. 1989; Harding et al. 1989).

In the case of the well-characterized ftz gene, a large $5^{\prime}$ regulatory region of $\sim 6 \mathrm{~kb}$ was shown to contain three individual cis-acting regulatory elements: A zebra element directed $l a c Z$ fusion gene expression in seven stripes localized primarily in the mesoderm; a neurogenic element was required for expression in neural precursor cells; an upstream element enhanced expression directed by the zebra element, particularly in the ectoderm (for summary, see Fig. 1A; Hiromi et al. 1985). The upstream element, which was active in both orientations relative to and at various distances from the zebra element, alone generated seven $f t z$-like stripes when linked to a heterologous promoter. This striped expression pattern was $f t z$-dependent, suggesting that the $f t z$ gene product might regulate the expression of its own gene, directly or indirectly. In addition, there was some indication that the products of some of the gap genes might regulate $f t z$ gene expression via interactions with the upstream element (Hiromi and Gehring 1987).

We have focused on the $f t z$ upstream element as a model to study the cis- and trans-acting factors involved in generating discrete patterns of transcription during Drosophila embryogenesis. Here, we present the results of a deletion analysis of the $f t z$ upstream element. We show that it contains several independent regulatory units, including at least two independent enhancers that direct expression of fusion genes in seven $f t z$-like stripes in a germ layer-restricted fashion. The enhancers are autoregulated independently by the wild-type $f t z$ product and contain multiple binding sites for purified $f t z$ homeo domain. These results suggest that $f t z$ protein is one of the trans-acting factors that, in conjunction with germ layer-restricted transcription factors, acts directly to regulate positively transcription of the $f t z$ gene.

\section{Results}

\section{Experimental approach}

Previous studies showed that the $f t z$ upstream element, defined by a 2574-bp KpnI-XbaI DNA fragment located between $\sim 3.5$ and $\sim 6.1 \mathrm{~kb}$ upstream of the transcription start site (Fig. 1A), contained sequences necessary and sufficient to generate stripes in transformed embryos when linked to a heterologous hsp 70 minimal promoter (Hiromi and Gehring 1987). We carried out a deletion analysis of the upstream element. Exonuclease III was used to generate sequential deletions from either end of the element, and restriction endonucleases were used to generate internal deletions (for details, see Experimental procedures). The resulting DNA fragments were assayed for their ability to activate a heterologous minimal promoter in the P-element-containing transformation vector HZ50PL (Hiromi and Gehring 1987). In this vector, the Escherichia coli lacZ gene is used as a reporter gene to monitor fusion gene expression.

Four types of fusion genes were analyzed following insertion into the Drosophila genome by P-element-mediated transformation (Rubin and Spradling 1982; Spradling and Rubin 1982) and establishment of a number of independent transformant lines: (1) $5^{\prime}$ deletion constructs, (2) 3' deletion constructs, (3) internal fragments, and (4) fragments inserted into HZ50PL in reverse orientation (Fig. 1B). Fusion gene expression was assayed by using the chromogenic substrate X-gal to stain wholemount embryos. Because $f t z-l a c Z$ fusion gene expression was most readily detectable during germ-band elongation, expression patterns were evaluated at this developmental stage.

Expression of full-length upstream element fusion genes The expression pattern of a fusion gene containing the $\sim 2.6-\mathrm{kb}$ upstream element fused to the minimal hsp70 promoter has been reported previously (UPHZ50H; Hiromi and Gehring 1987; Dearolf et al. 1989|. We have analyzed the expression pattern of this fusion gene in more detail. As shown in Figure 2, UPHZ50H was expressed in seven $f t z$-like stripes, which were readily detectable at the germ-band extension stage. These stripes extended all the way around the outer surface of the embryo and were strongest laterally. The stripes were of unequal intensity. As is the case for $f t z$ RNA and protein, the seventh stripe was the strongest and broadest. In addition, stripes one and six were weaker than stripes two through five. Because $\beta$-galactosidase is extremely stable in transformant embryos, stripes were still detectable in the even-numbered parasegments after the formation of 
Pick et al.

Figure 1. $f t z$ upstream element $-1 a c Z$ fusion genes. $(A \mid$ The structure of the $f t z$ gene is shown. The indicated $10-\mathrm{kb} K p n I$ fragment complemented the defects of $f t z$ mutants (Hiromi et al. 1985). The transcribed region is indicated by an open box. The TATA homology at $-26 \mathrm{bp}$ (Dearolf et al. 1989; L. Pick and W.J. Gehring, unpubl.), the putative translation start and stop codons, and the 150-bp intron (hatched box) are indicated (Kuroiwa et al. 1984; Laughon and Scott 1984). The $\sim 6-\mathrm{kb}$ of $5^{\prime}$-flanking sequence includes three cis-regulatory regions. The zebra element, which contains $\sim 600$ bp upstream of the transcription start site, directs expression of $f t z-l a c Z$ fusion genes in seven stripes localized primarily to the mesoderm. In addition, the zebra element appears to contain sequences that mediate interstripe repression to generate the $f t z$ seven-stripe pattern at cellularization (Dearolf et al. 1989). The neurogenic element, located within the next $2 \mathrm{~kb}$ is re quired for expression in the neural precursor cells in which $f t z$ is normally expressed. The next $1 \mathrm{~kb}$ of sequence appears to be dispensable for $f t z$ expression and function, and the remaining $\sim 2.6$ $\mathrm{kb}$ contains the upstream element that enhances expression directed by the zebra element, particularly in the ectoderm (Hiromi and Gehring 1987) (K) KpnI; (X) XbaI; (B) BalI. (B) Upstream element-lacZ fusion genes used in this study are summarized. Fusion genes contain either the full-length or various portions of the $f t z$ upstream element inserted upstream of a minimal promoter in the P-element transformation vector HZ50PL. The minimal promoter and trailer sequences were derived from the Drosophila hsp 70 gene (Hiromi and Gehring 1987). The fusion genes are (1.) 5' deletion constructs, (2.) 3' deletion constructs, (3.) internal fragments, and (4.) upstream element fragments inserted in reverse orientation relative to the minimal promoter in HZ50PL. The number of transformant lines examined is indicated in parentheses to the right of each fusion gene. Each deletion end point is indicated, using the numbering system of Harrison and Travers (1988). Position 1 corresponds to the 5' end of the upstream element.

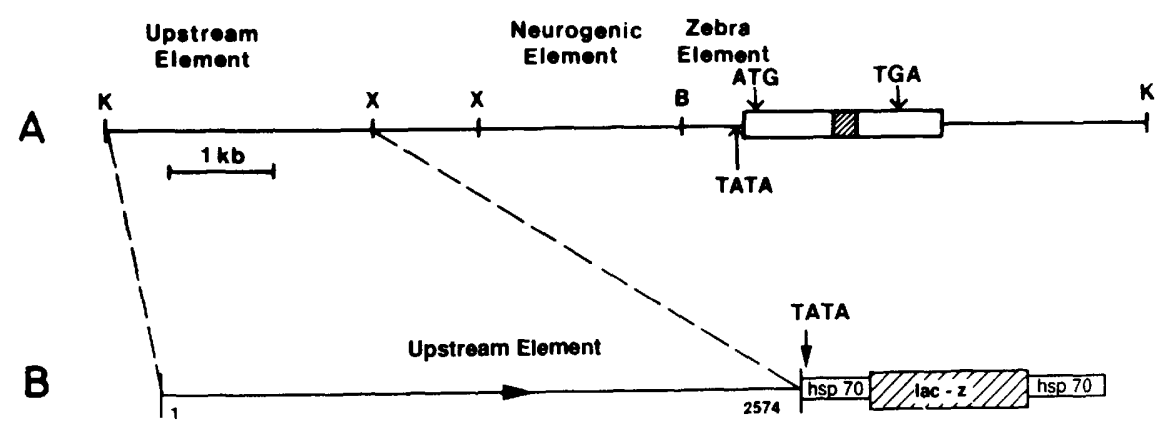

1. 289

$$
\begin{aligned}
& \text { 5.A (4) } \\
& 5 \text { B (7) } \\
& 5 . \text { (5) }^{\circ} \\
& \text { 5D (3) } \\
& \text { SE (5) } \\
& 5 F \text { (5) }
\end{aligned}
$$

2.

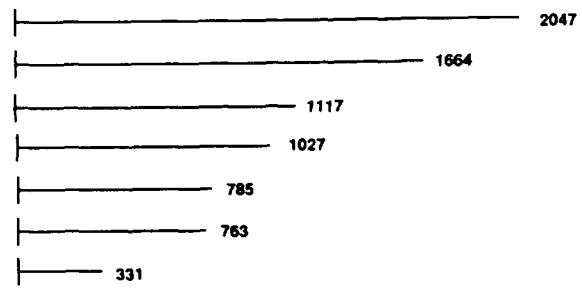

3.

4.

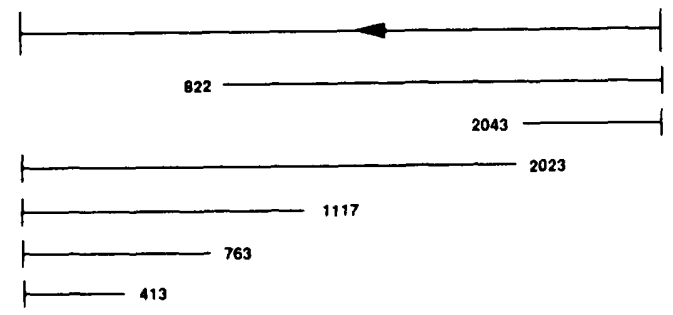

$\begin{array}{ll}\text { Rev 5B } & \text { (3) } \\ \text { Rev } 2043 & \text { (7) } \\ \text { Rev 2023 } & \text { (5) } \\ \text { Rev 3C } & \text { (8) } \\ \text { Rev 3F } & \text { (9) } \\ \text { Rev 413 } & \text { (6) }\end{array}$

segmental boundaries, confirming that they lie within the wild-type $f t z$ domain (data not shown).

The precise localization of the stripes was investigated further. As reported previously (Dearolf et al. 1989), the seven stripes each extended to the ectodermal cells at the periphery of the embryo. However, in whole-mount embryos, the strong ectodermal staining might obscure the visualization of staining in the underlying meso- derm. Therefore, thin sections of stained UPHZ5OH transformant embryos were analyzed. As shown in Figure $3 \mathrm{~A}, \beta$-galactosidase was expressed with roughly equal intensity in the ectoderm and mesoderm in all seven stripes. The internal stain bordered the granular yolk layer and was confined to sharp bands corresponding in width to those in the ectoderm. Thus, the $\sim 2.6$-kb upstream element contains cis-acting DNA se- 


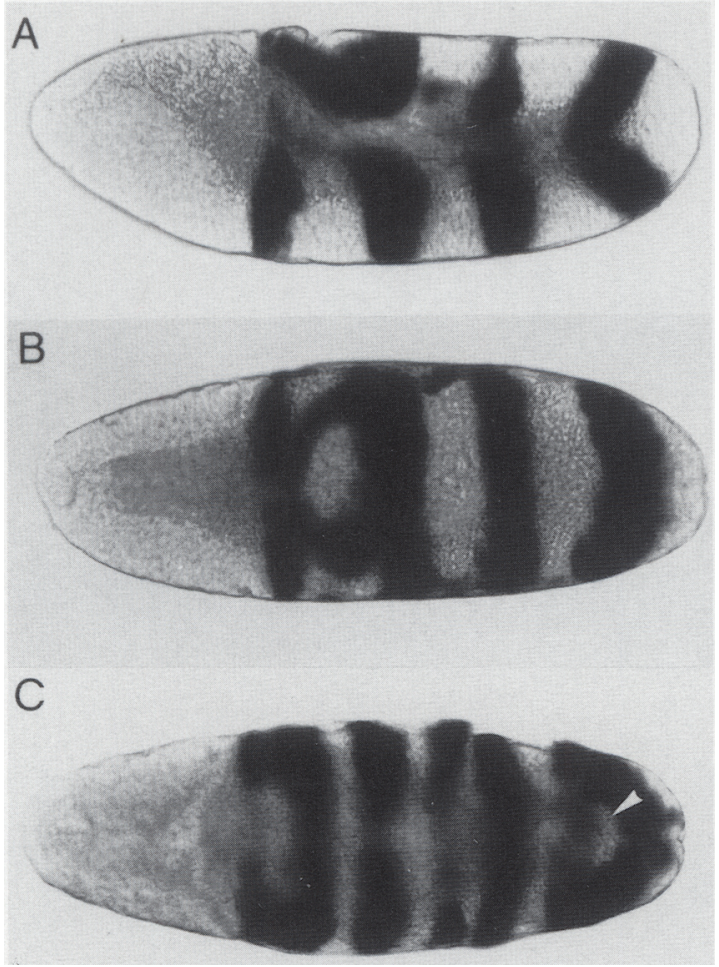

Figure 2. Expression of full-length upstream element fusion genes. Transformant embryos carrying fusion gene UPHZ $50 \mathrm{H}$, which contains the full-length upstream element, were stained for $\beta$-galactosidase activity by using the chromogenic substrate $\mathrm{X}$-gal. Photographs of whole-mount embryos are shown (anterior ends of the embryos to the left). (A) Lateral view, germband extension stage. (B) Same embryo as in $A$, rotated and viewed from the ventral side. The stripes encircle the embryo. (C) Embryo at a slightly later stage, dorsal view. The fourth stripe is almost parallel to the anterior-posterior axis at this time but has not reached the posterior tip. The plane of focus is on the internal portion of this stripe, showing staining in the mesoderm, bordering the granular yolk platelets (arrowhead).

quences that direct fusion gene expression in seven stripes in both the ectoderm and the mesoderm.

\section{Expression of 5' deletion constructs}

The expression patterns of fusion genes containing the $5^{\prime}$ deletion constructs were examined first. Sequential deletions of 289,822 , and $1110 \mathrm{bp}$ from the $5^{\prime}$ end of the upstream element (fusion genes $5^{\prime} \mathrm{A}-5^{\prime} \mathrm{C}$ ) did not detectably alter the pattern of fusion gene expression (Fig. 4A). Fusion genes $5^{\prime} \mathrm{D}$ and $5^{\prime} \mathrm{E}$, which contain 1072 and $794 \mathrm{bp}$ from the proximal portion of the upstream element, were also expressed in a striped pattern that resembled that directed by the full-length upstream element (Fig. 4B,C). However, these fusion genes were expressed more weakly than longer fusion genes. This weakness was particularly clear on the dorsal and ventral sides of the embryo where the stripes narrow, resulting in a triangular appearance of the stripes when viewed laterally (Fig. 4B,C); and in the first stripe,

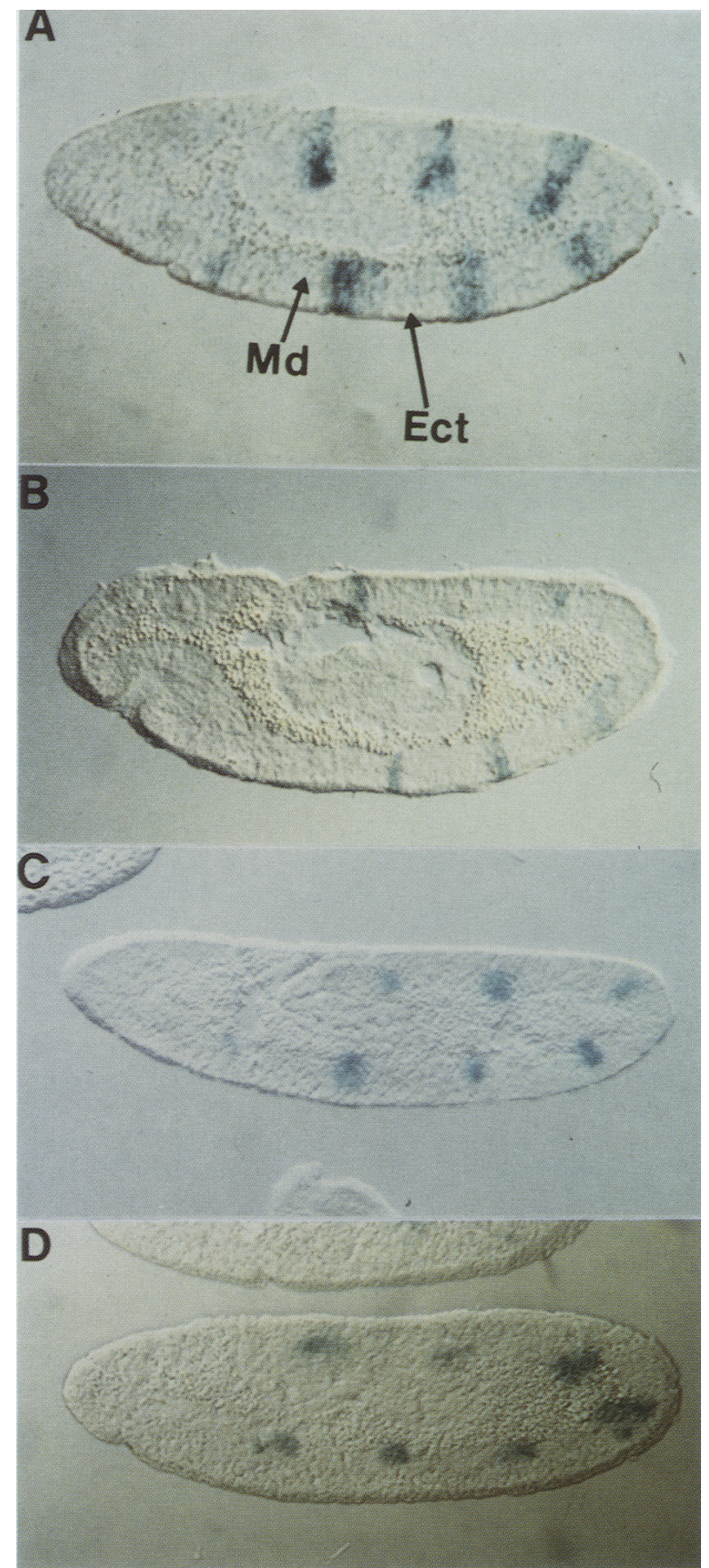

Figure 3. Sections through transformant embryos. Examination of internal localization of fusion gene expression. Transformant embryos at the germ-band extension stage were stained and sectioned as described in Experimental procedures. (A) UPHZ50H transformant embryo. The bands of $\beta$-galactosidase extend from the periphery of the embryo through the mesodermal layer. Mesodermal ( $\mathrm{Md}$ ) and ectodermal (Ect) germ layers are indicated. $(B) 5^{\prime} \mathrm{E}$ transformant embryo. The striped pattern resembles $A$, but the staining is weaker. Stripes 1 and 6, which are the weakest stripes, are difficult to visualize. $(C)$ IntB transformant embryo. (D) IntA transformant embryo. In $C$ and $D$, staining is detectable only in the mesoderm. 
Figure 4. A proximal enhancer contains two regulatory units. Localization of $\beta$-galactosidase activity in transformant embryos carrying the $5^{\prime}$ deletion fusion genes. Whole-mount embryos were stained for $\beta$-galactosidase activity at the germ-band extension stage. $(A) 5^{\prime} \mathrm{C}$ transformant embryo, lateral view. The pattern and intensity of staining is indistinguishable from UPHZ $50 \mathrm{H}$ transformants. ( $B$ and $C) 5^{\prime} \mathrm{D}$ and $5^{\prime} \mathrm{E}$ transformant embryos, lateral views. Staining of $5 ' D$ and $5^{\prime} \mathrm{E}$ is weaker than that of $5^{\prime} \mathrm{C}$, but all stripes are visible. Because staining is strongest laterally, stripes appear faint as they round the dorsal and ventral surfaces of the embryo. (D) Same embryo as $C$, rotated and viewed from the dorsal side. Staining extends around the entire surface of the embryo. $(E) 5^{\prime} \mathrm{F}$ transformant embryo, lateral view. No $\beta$-galactosidase activity is detectable. $(F)$ IntB transformant embryo, lateral view. $(G)$ Same embryo as in $F$, rotated and viewed from the dorsal side. The plane of focus is on the top edge of the embryo. Note that the mesodermal stripes appear to encircle the inner layer of the germ band. In both $F$ and $G$, the stripes are detectable only internally. (H) Rev 2043 transformant embryo, lateral view. All stripes are visible and extend out to the periphery.

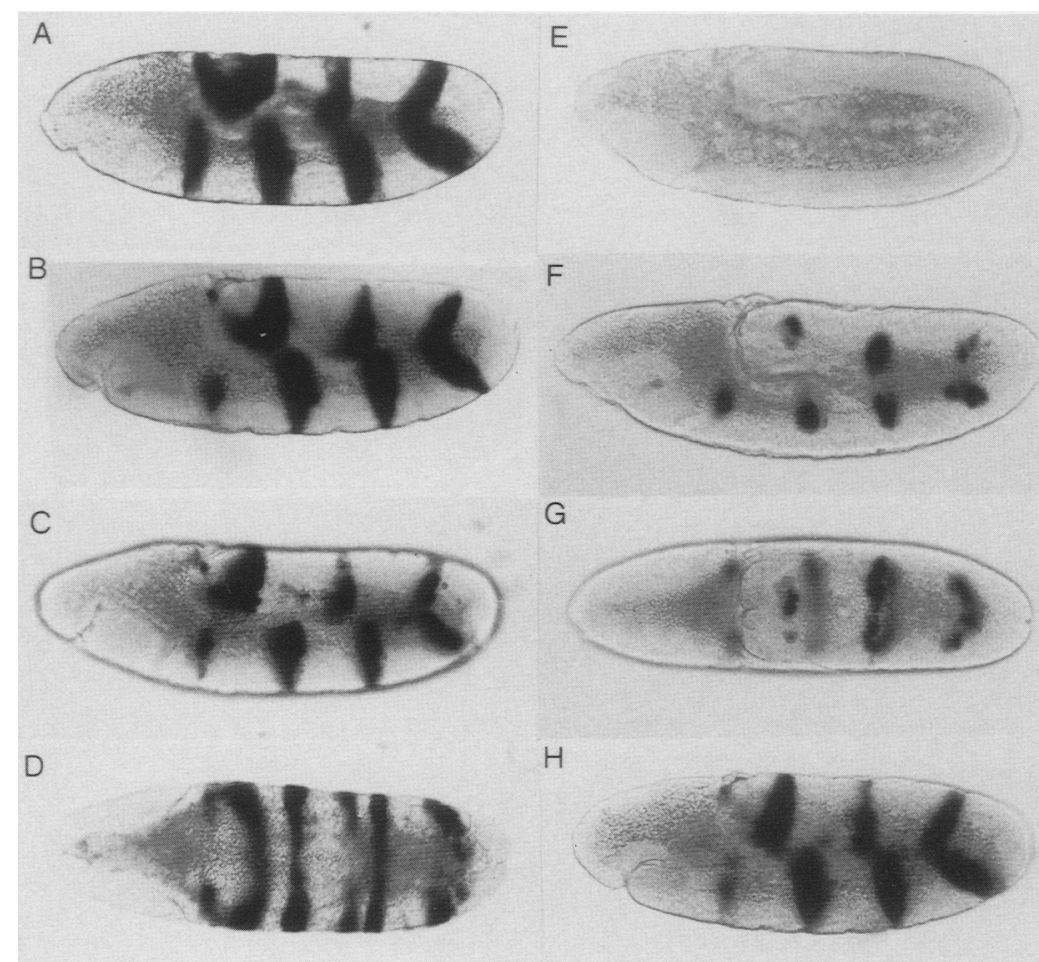

which was often barely detectable in $5^{\prime} \mathrm{D}$ and $5^{\prime} \mathrm{E}$ transformant embryos (cf. stripe 1 in Fig. 4A with that in B and $\mathrm{Cl}$. Although the stripes appeared to be narrower, they did extend to the periphery of the embryo and around the entire surface, demonstrating ectodermal localization (Fig. 4D). Examination of sections through these transformant embryos demonstrated that $\beta$-galactosidase was expressed in both the mesoderm and the ectoderm in all seven stripes; the width of the stripes was roughly the same in both germ layers. The relative weakness of these shorter fusion genes was particularly evident in sectioned embryos because all of the stripes were not always readily detectable in each section examined (Fig. 3B). These fusion genes define a proximal element of $794 \mathrm{bp}$ that directs fusion gene expression in seven $f t z$-like stripes in the mesoderm and ectoderm.

\section{Further analysis of the proximal element}

As shown in Figure 4E, a shorter fusion gene, 5' $\mathrm{F}$, containing the terminal $211 \mathrm{bp}$ from the $3^{\prime}$ end of the upstream element, did not express detectable levels of $\beta$ galactosidase. This suggested that cis-acting regulatory sequences in the upstream proximal element were located within the 583 bp between positions 1780 and 2363. To test whether or not this 583-bp region contained sequences sufficient for the generation of the ectodermal and mesodermal stripes, a fusion gene containing only this portion of the upstream element was analyzed. As shown in Figures $3 \mathrm{C}$ and 4, F and G, fusion gene IntB expression was detectable only in the mesoderm, again in seven $f t z$-like stripes (the term stripe describes the patch-like mesodermal staining|. Thus, se- quences within each of the 211- and 583-bp portions of the proximal element are necessary but not sufficient to generate detectable levels of expression in the ectodermal stripes.

Finally, a fusion gene containing the terminal $531 \mathrm{bp}$ of the upstream element was expressed in seven stripes in the ectoderm and in the mesoderm, as determined by examination of sectioned transformant embryos /data not shown). In addition, because this 531-bp fragment generated a $f t z$-like seven stripe pattern when inserted into HZ50PL in reverse orientation, the information in the upstream proximal element appears to function in an orientation-independent fashion (Fig. $4 \mathrm{H}$, fusion gene Rev 2043).

We conclude that sequences in the proximal element direct specific expression when linked to a heterologous promoter in an orientation-independent fashion, indicating that the proximal element functions as an enhancer. This proximal enhancer appears to contain two separate regulatory units: a mesodermally restricted element, Prox A, and a second element, Prox B that, when combined with Prox A, directs high levels of expression in the ectodermal stripes (see Fig. 10A, below).

\section{Expression of the $3^{\prime}$ deletion constructs}

Although the pattern of expression directed by the proximal enhancer was qualitatively similar to that directed by the full-length upstream element, the relative weakness of fusion genes $5^{\prime} \mathrm{D}, 5^{\prime} \mathrm{E}$, and Rev 2043 suggested that the proximal element does not contain all of the regulatory information present in the upstream element. Therefore, the expression patterns of $\beta$-galactosidase di- 
rected by the $3^{\prime}$ deletion constructs were examined. Deletion of 527 or $910 \mathrm{bp}$ from the $3^{\prime}$ end of the upstream element (fusion genes $3^{\prime} \mathrm{A}$ and $3^{\prime} \mathrm{B}$ ) resulted in drastically reduced $\beta$-galactosidase expression in the ectoderm (Fig. 5A). However, mesodermal staining in seven stripes in the regions in which the full-length UPHZ50H is expressed was retained. A shorter fusion gene, IntA, containing a 1171-bp internal fragment from the distal portion of the upstream element, harbors sequences sufficient to direct $\beta$-galactosidase expression in these seven mesodermal stripes, defining a distal element in the upstream element (Fig. 5B,C). The mesodermal localization of $\beta$-galactosidase is clearly visualized in wholemount embryos and in thin sections of IntA transfor-

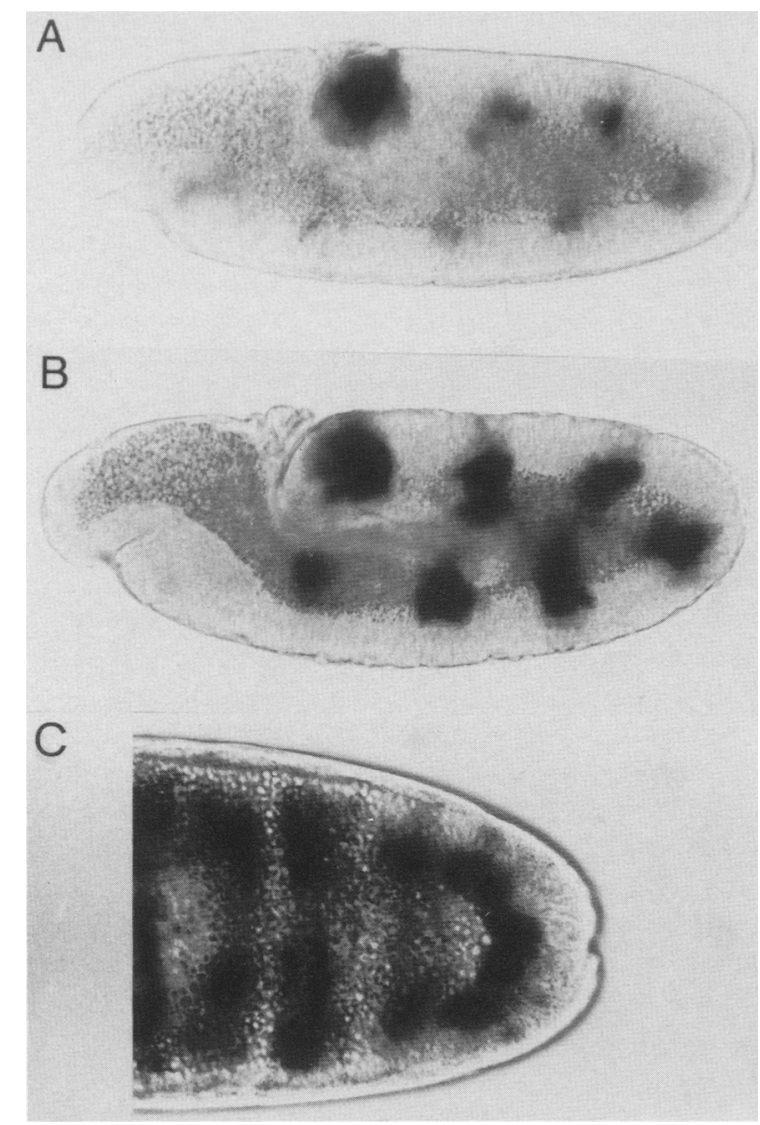

Figure 5. The distal portion of the upstream element contains a mesodermally restricted regulatory element. Expression of $3^{\prime}$ deletion fusion genes was analyzed as described above. (A) $3^{\prime} \mathrm{A}$ transformant embryo, lateral view. The stripes are graded in intensity: Stripe seven is the strongest; stripe one is the weakest. This gradient-like expression resembles the expression of zebra element-containing fusion genes. In contrast to this, the mesodermal stripes directed by Prox A (see Fig. 4F) appear to have sharper borders and are not graded in intensity. $(B)$ IntA transformant embryo, lateral view. For all transformant lines examined, fusion gene IntA was expressed more strongly than fusion genes $3^{\prime} \mathrm{A}$ or $3^{\prime} \mathrm{B}$. $(C)$ Magnification of the posterior end of the embryo shown in $B$, rotated and viewed from the dorsal side. This view highlights the mesodermal localization of the fourth stripe. For all embryos shown, staining is primarily mesodermal. mant embryos (Fig. 3D). The pattern of expression of these distal element-containing fusion genes resembles that directed by the zebra element alone (Hiromi and Gehring 1987; Dearolf et al. 1989). No $\beta$-galactosidase activity was detected in transformant embryos carrying the shorter fusion genes $3^{\prime} \mathrm{C}$ through $3^{\prime} \mathrm{G}$ /data not shown). Thus, sequences necessary for expression directed by the distal regulatory element are located between positions 1117 and 1502 of the upstream element. In addition, we believe that sequences within this distal element enhance the expression of proximal enhancercontaining fusion genes because UPHZ5OH, 5'A, 5'B, and $5^{\prime} \mathrm{C}$, which still contain portions of the distal element, were expressed more strongly than $5^{\prime} \mathrm{D}, 5^{\prime} \mathrm{E}$, or Rev 2043, which contain only the proximal enhancer.

\section{Expression of deletion constructs in reverse orientation}

Hiromi and Gehring (1987) showed previously that insertion of the $\sim 2.6-\mathrm{kb}$ upstream element into HZ50PL in reverse orientation (fusion gene UPHZ50T) resulted in fusion gene expression in a single stripe in PS 4, which was readily detectable at the cellular blastoderm stage. Following this phase of expression, UPHZ50T was expressed in the seven stripes characteristic of the forward orientation construct, although strong staining in PS 4 persisted. In this fusion gene, the 5' end of the upstream element was placed $\sim 50 \mathrm{bp}$ upstream of the transcription start site. When the upstream element was inserted in reverse orientation 154 or $2.5 \mathrm{~kb}$ farther away from the transcription start site, this PS 4-specific expression was no longer detected (Y. Hiromi and L. Pick, unpubl.). These results suggested that regulatory sequences at the $5^{\prime}$ end of the upstream element might function in a distance- and orientation-dependent manner to direct PS 4-specific expression at the blastoderm stage. To test this possibility, several of the $3^{\prime}$ deletion constructs were inserted into HZ50PL in reverse orientation.

As shown in Figure 6A, $\beta$-galactosidase expression directed by fusion gene Rev 2023 was detectable in a strong band in PS 4 . This fusion gene also contains the distal regulatory element, which directs $\beta$-galactosidase expression in seven mesodermal stripes that are only weakly detectable at this early developmental stage. These mesodermal stripes increase in intensity as germband elongation proceeds, demonstrating that the upstream distal element functions in an orientation-independent fashion (Fig. 6B). Staining in PS 4 remains very strong at this late stage, overlaying mesodermal stripe 2 and almost obscuring visualization of the seven $f t z$-like mesodermal stripes.

Fusion genes Rev $3^{\prime} \mathrm{C}, 3^{\prime} \mathrm{F}$, and 413 , which contain 1117,763 , and $413 \mathrm{bp}$ from the $5^{\prime}$ end of the upstream element, do not contain information sufficient to direct fusion gene expression in seven $f t z$-like stripes. However, as shown for the shortest of these fusion genes in Figure $6 \mathrm{C}, \beta$-galactosidase was detectable in the single PS 4 stripe at cellular blastoderm. At later stages, expression in this stripe increased in intensity, but no $\mathrm{ftz}$ - 
Pick et al.

Figure 6. PS 4-specific activator is located at the $5^{\prime}$ end of the upstream element. Expression patterns of reverse orientation fusion genes are shown. (A) Rev 2023 transformant embryo at early germ-band extension. A single strong stripe is detectable in PS 4. Weak mesodermal stripes in every other parasegment are becoming visible because Rev 2023 contains the distal regulatory element. (B) Rev 2023 transformant embryo at late germ-band extension. The PS 4 stripe (arrow) overlays mesodermal stripe two. The seven $\mathrm{ftz}$ like stripes are clearly detectable at this stage. However, except for stripe seven, these stripes are much weaker than the PS 4-specific stripe.

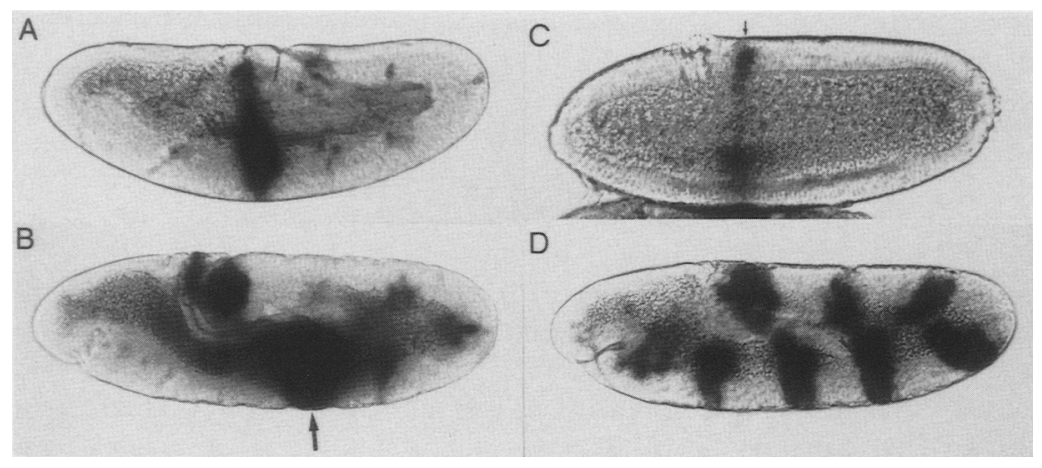
(C) Rev 413 transformant embryo at the cellular blastoderm stage. A single stripe is detectable in the primordia of PS 4 (arrow). No other stripes are detectable during embryonic development (see also Fig. 7M). (D) Rev 5'B transformant embryo at germ-band extension. The seven-stripe staining pattern is indistinguishable from that of 5'B transformant embryos. Staining anterior to the cephalic furrow was observed for some transformant lines carrying various fusion genes, as noted previously for other $f t z-l a c Z$ fusion genes (Hiromi et al. 1985; Dearolf et al. 1989). Sequences in the transformation vector may be responsible for this sporadic expression.

like striped expression was detected (data not shown). As was the case for the forward-orientation fusion genes, expression in the PS 4 stripe became weaker when the distal enhancer was removed, suggesting that this expression can also be enhanced by the distal enhancer (cf. Fig. $6 \mathrm{~A}$ with $6 \mathrm{C}$ and $6 \mathrm{~B}$ with $7 \mathrm{M}$ ). Thus, sequences in the $413 \mathrm{bp}$ at the $5^{\prime}$ end of the upstream element are necessary and sufficient to direct fusion gene expression in a single stripe in PS 4. In addition, this PS 4-specific activator appears to be physically separable from the enhancers that generate the seven $f t z$-like stripes.

When the PS 4-specific activator and the terminal portion of the distal enhancer are deleted, the remaining portion of the upstream element directs fusion gene expression in seven stripes in an orientation-independent fashion (fusion gene Rev 5'B; Fig. 6D; cf. Fig. 4A). Thus, the pattern-forming elements in the upstream element that are involved in the generation of the seven $f t z$-like stripes act as enhancers, whereas the PS 4-specific activator functions in an orientation-dependent fashion.

\section{Autoregulation of individual enhancers}

The expression of the fusion gene containing the fulllength upstream element (UPHZ50H) was drastically reduced in $f t z$ mutant embryos, indicating that wild-type $\mathrm{ftz}$ gene product is required for striped expression directed by the upstream element (Hiromi and Gehring 1987). In hairy (h) mutants, in which the $f t z$ stripes are broadened such that each stripe is about twice its normal width /Carroll and Scott 1986; Howard and Ingham 1986), UPHZ50H expression was correspondingly broadened, presumably in response to the ectopic expression of the endogenous $\mathrm{ftz}$ gene (Hiromi and Gehring 1987; Fig. 7A-Cl. Is this autoregulation a property of the intact, full-length upstream element, that is, is autoregulation of the individual enhancers mediated through a single $f t z$-responsive region in the upstream element, or are the individual enhancers independently autoregulated?

To address this question, we have examined the ex- pression of fusion genes containing each individual upstream regulatory element in $f t z$ and $h$ mutant embryos, as shown in Figure 7. Expression of fusion genes IntA, $5^{\prime} \mathrm{E}$, and IntB (Fig. 7D,G,J) containing the distal enhancer, the proximal enhancer, or Prox A, respectively, was reduced to undetectable levels in $\mathrm{ftz}$ mutant embryos (Fig. 7E,H,K).

Furthermore, expression of each of these fusion genes was expanded in $h$ mutant embryos (Fig. $7 \mathrm{~F}, \mathrm{I}, \mathrm{L}$ ). As is the case for the endogenous $f t z$ protein (Lawrence and Johnston 1989), the stripes had a broadened and irregular appearance. Thus, each individual upstream regulatory element appears to be a target for autoregulation by the $f t z$ gene product. Interestingly, the germ layer specificities of the individual fusion genes were retained even under conditions of ectopic $f t z$ expression. For fusion genes Int $A$ and IntB, which are expressed principally in the mesoderm, $\beta$-galactosidase was detected in broadened stripes that retained their mesodermal localization (see Fig. 7F,L).

In contrast to this $f t z$-dependent seven-stripe expression, the pattern of expression of fusion gene Rev 413 was qualitatively unaffected in either $f t z$ or $h$ mutant embryos (Fig. 7M-O). Thus, the PS 4-specific activator does not appear to be a target for $f t z$ autoregulation.

\section{Interaction of $\mathrm{ftz}$ homeo domain with the upstream element}

The genetic experiments presented above demonstrate that wild-type $f t z$ gene product is required for expression of fusion genes in seven stripes. To investigate whether this observed $f t z$ dependence could reflect an indirect requirement for wild-type $f t z$ activity or a direct interaction between $f t z$ product and enhancer DNA, we have used a DNase I protection assay to systematically screen the upstream element for potential $f t z$ protein-binding sites. Preliminary experiments performed with either full-length $f t z$ protein or isolated $f t z$ homeo domain demonstrated that in all cases, identical sites were protected (data not shown; for an example, see Fig. 8B, lanes 


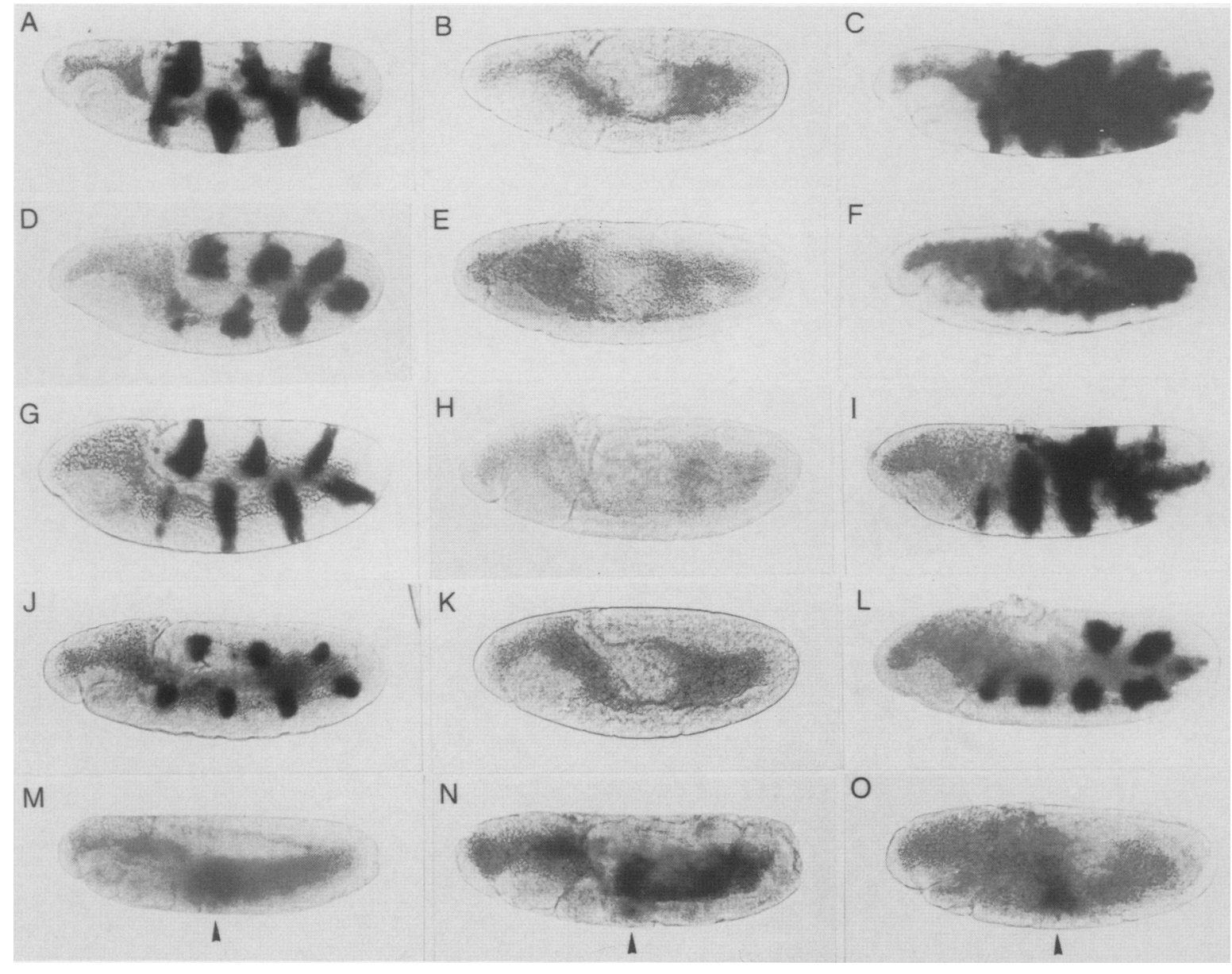

Figure 7. Individual upstream element enhancers are autoregulated. Fusion gene expression was examined in $f t z$ and $h$ mutant backgrounds. Crosses were carried out as described in Experimental procedures. In a separate series of experiments, embryos were double-stained with an anti-engrailed monoclonal antibody (kindly provided by P. Lawrence) to identify homozygous mutant embryos. $(A, D, G, I$, and $M)$ wild-type embryos; $(B, E, H, K$, and $N) f t z$ mutant embryos; $(C, F, I$, $L$, and $O) h$ mutant embryos. Transformant embryos carried the following fusion genes: $(A-C) \mathrm{UPHZ} 50 \mathrm{H} ;(D-F)$ IntA; $(G-I) 5^{\prime} \mathrm{E}_{;}(J-L)$ IntB; $(M-O)$ Rev 413 . Arrows indicate the single stripe in PS 4. The relative weakness of proximal enhancer-containing fusion genes 5 'E and IntB may reflect a decreased responsiveness to $\mathrm{ftz}$ protein, as compared with fusion genes that also contain the distal enhancer. In both wild-type embryos and in $h$ mutants, the seven $f t z$-like stripes are stronger and extend more posteriorly in UPHZ50H transformant embryos than in $5^{\prime} \mathrm{E}$ transformants and in IntA than in IntB transformants, respectively. Lawrence and his co-workers (1987) and Lawrence and Johnston (1989) observed that by the onset of gastrulation, $f t z$ stripes are asymmetric and graded, the highest levels of expression being in the anterior region of each stripe. We suggest that the full-length upstream element may respond more readily to the lower levels of $f t z$ protein that are present in the posterior portions of the even-numbered parasegments, whereas the proximal enhancer may respond only to the higher levels of protein present in the anterior portion of each parasegment.

5 and 6). Because the $f t z$ homeo domain had been purified to homogeneity in a soluble form (M. Müller and W.J. Gehring, unpubl.), we chose to use it for the more extensive footprint analysis. Individual $\sim 500$-bp DNA fragments were subcloned, radioactively labeled separately on both strands, and incubated with increasing amounts of $f t z$ homeo domain, as described in Experimental procedures. Representative examples of this analysis are shown in Figure 8. Using a DNA fragment containing part of the proximal enhancer, a single region between positions 2197 and 2214 was protected at low concentrations of $f t z$ homeo domain (Fig. 8A, lanes $1-6)$. As the amount of $f t z$ homeo domain added to the reaction was increased, three lower affinity sites were detected (Fig. 8B). All four binding sites were protected in a similar manner by high concentrations of full-length $f t z$ protein (Fig. 8B, lane 6). Using a DNA fragment containing part of the distal enhancer, several binding sites were also identified (Fig. 8C and see below).

A summary of the results of the complete analysis is shown in Figure 9. Because different binding sites were protected against DNase I digestion at different concentrations of homeo domain, we have grouped the protected regions into three classes (high, medium, and low affinity; see Fig. 9). Within the 1790 bp analyzed in detail, 20 regions were found to be protected from DNase I digestion (Fig. 9). Most of these regions fall into the medium-affinity class (hatched boxes). Two binding sites 
Pick et al.

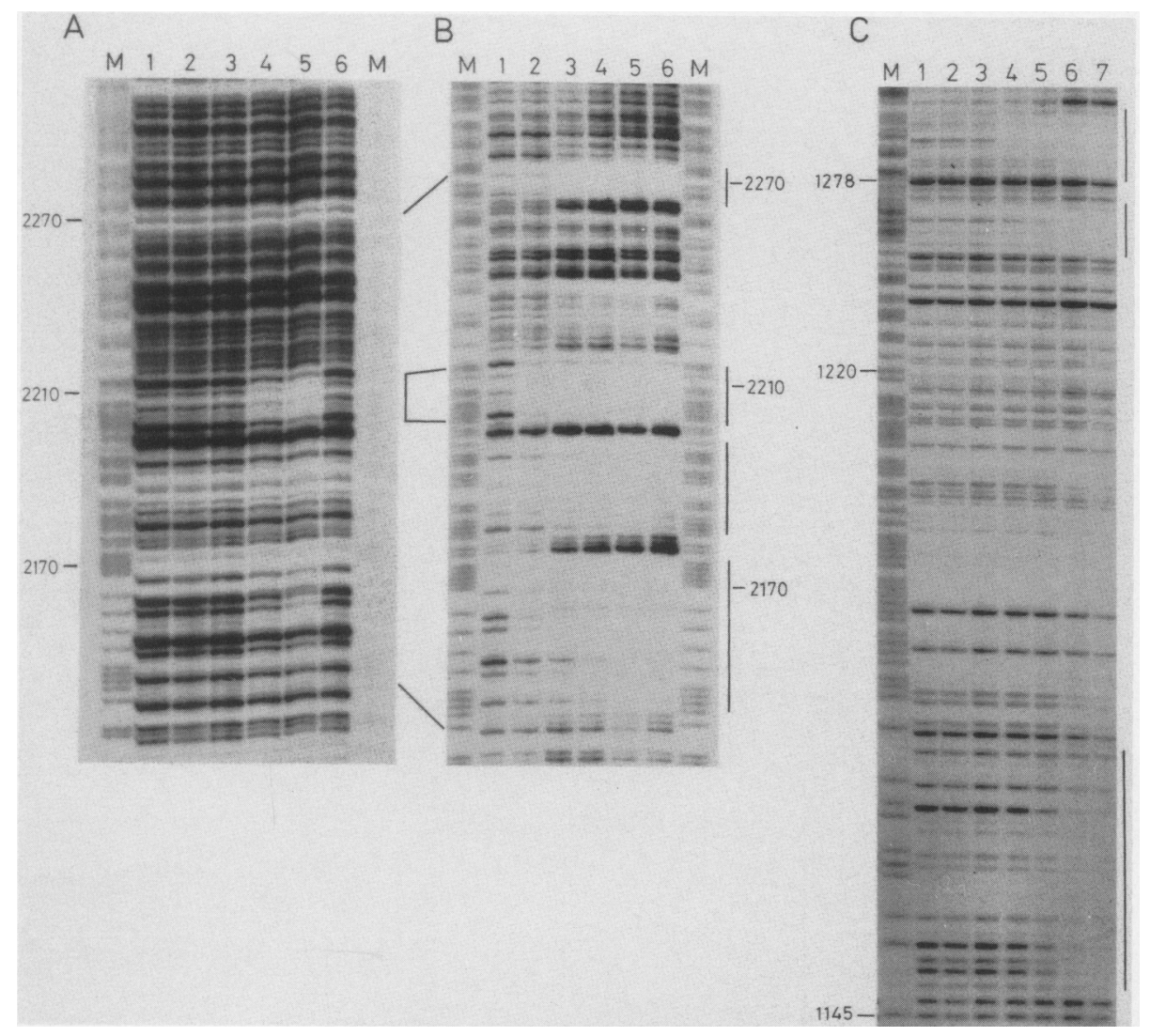

Figure 8. $f t z$ homeo domain binds to sequences within the upstream element. The interaction of $f t z$ homeo domain with the upstream element was analyzed by DNase I protection assay. Increasing amounts of purified proteins were incubated with a DNA fragment, $5^{\prime}$-end-labeled at position 2047, and extending to position 2367 (Fig. 9A,B) or a DNA fragment, $5^{\prime}$-end-labeled at position 1117, extending to position 1394 (Fig. 9C). After partial digestion with DNase I, nucleic acids were purified and separated on $6 \%$ polyacrylamide gels. Autoradiographs are shown. The proteins used were purified $f t z$ homeo domain $(A$, lanes $2-6 ; B$, lanes $2-5 ; C$, lanes 2-7) or full-length $f t z$ protein $(B$, lane 6$)$. The amounts of protein used were as follows: $(A)$ No protein (lanes 1 and 6$), 3$ ng (lane 2), $9 \mathrm{ng}$ (lane 3), $26 \mathrm{ng}$ (lane 4), and $78 \mathrm{ng}$ (lane 5); (B) no protein (lane 1), $78 \mathrm{ng}$ (lane 2), $390 \mathrm{ng}$ (lane 3), $780 \mathrm{ng}$ (lane 4), $1600 \mathrm{ng}$ (lane 5), and $9000 \mathrm{ng}$ (lane 6); (C) no protein (lane 1), $9 \mathrm{ng}$ (lane 2), $26 \mathrm{ng}$ (lane 3), $78 \mathrm{ng}$ (lane 4), $234 \mathrm{ng}$ (lane 5), $780 \mathrm{ng}$ (lane 6), and 1600 ng (lane 7). (M) G + A reaction cleavage products of the corresponding DNA fragments. Bars indicate protected regions. Lines between $A$ and $B$ indicate the corresponding nucleotide sequences on the two gels.

required lower amounts of $f t z$ homeo domain for protection (Fig. 8A, positions 2197-2214; Fig. 8C, positions 1279-1309), whereas five regions were protected only by very high concentrations of homeo domain lopen boxes). With respect to the regulatory elements identified in transgenic flies, we find that the 794-bp proximal enhancer (positions 1780-2574) contains one high-, seven medium-, and two low-affinity binding sites. Of these sites, three lie within the Prox B portion of the proximal enhancer. The region between these regulatory elements (positions 1502-1780) that does not appear to be required for $l a c Z$ fusion gene expression contains one medium-affinity-binding site, one extended medium-affinity site, and one low-affinity site.

The distal enhancer has been more difficult to analyze because the $5^{\prime}$-most 660 bp of this element is extremely AT rich (Harrison and Travers 1988), making DNase I protection analysis of this region virtually impossible. This region was essentially covered by $f t z$ homeo domain at concentrations used to identify medium- and low-affinity sites, and no individual footprints could be identified. The remaining $710 \mathrm{bp}$ of the distal enhancer has been analyzed systematically, revealing one high-, four medium-, and one low-affinity binding site (Figs. 8C and 91.

\section{Discussion}

The upstream element contains multiple regulatory units

The $f t z$ upstream element contains sequences that mediate an autoregulatory feedback loop, which maintains $f t z$ expression in seven stripes in the developing Drosophila embryo. We carried out a deletion analysis of this $\sim 2.6-\mathrm{kb}$ element and have shown that it contains a number of separable regulatory elements that are summarized in Figure 10A. A distal regulatory element directs fusion gene expression primarily in the mesoderm and appears to enhance expression of proximal elementcontaining fusion genes. Sequences necessary for expres- 


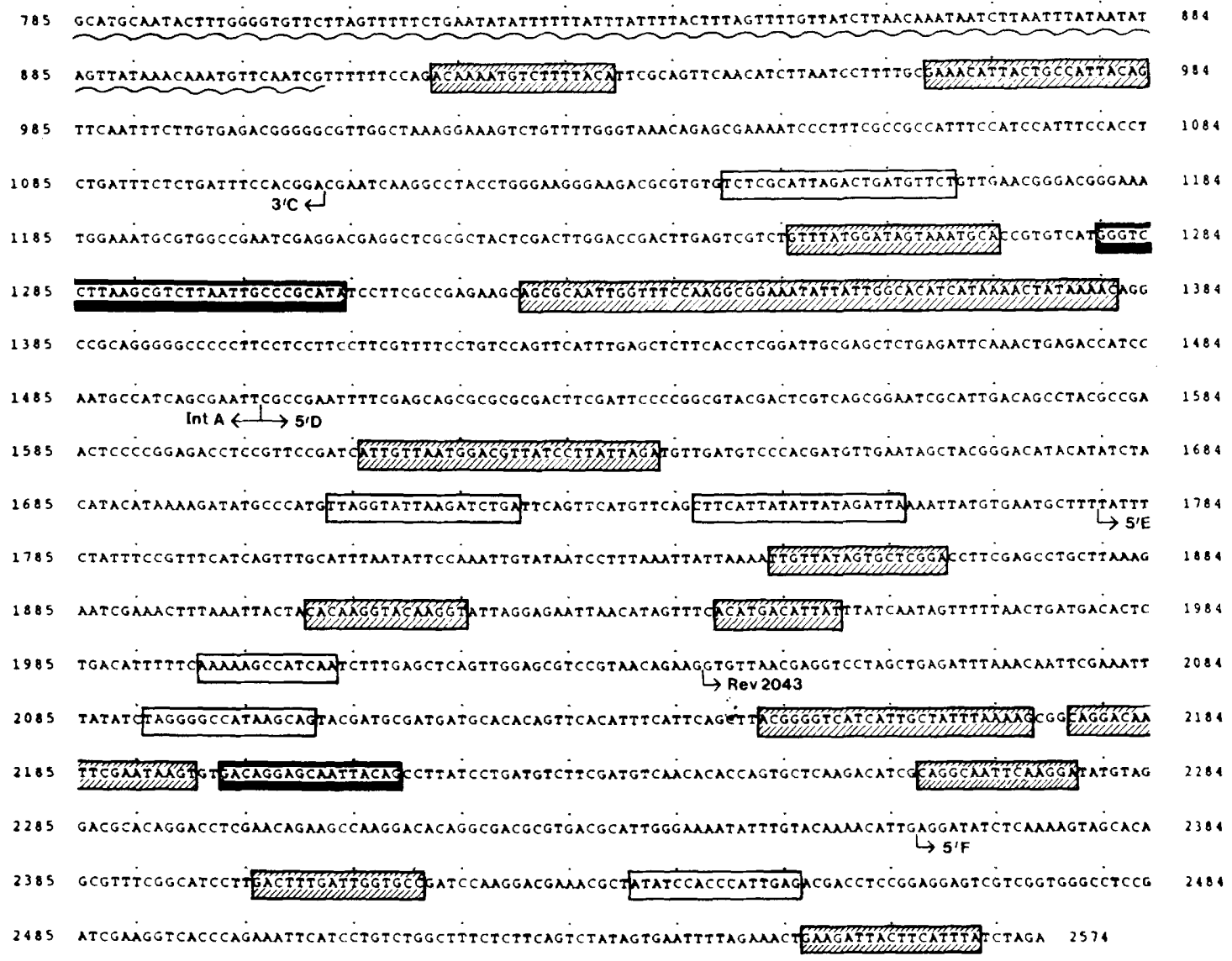

Figure 9. Summary of $f t z$ homeo domain-binding sites in the upstream element. The sequence of the $f t z$ upstream element from an SphI site at position 785 to the $X b a I$ site at position 2574 is shown (for the entire upstream element sequence, see Harrison and Travers 1988). Footprinted regions are boxed in and indicate the extent of the region protected from DNase I digestion by $f t z$ homeo domain. The binding sites have been classified according to the amount of $f t z$ homeo domain required for protection of half of the fragments present in the binding reaction. High-affinity sites (heavily outlined boxes) required between 26 and $78 \mathrm{ng}$ of $f t z$ homeo domain, medium-affinity sites (hatched boxes) required $\sim 390 \mathrm{ng}$, and low-affinity sites (open boxes) required $780 \mathrm{ng}$ or more. The wavy line extending from positions 785-906 indicates an AT-rich region for which DNase I protection experiments were extremely difficult to analyze (see text). Several other short $(6-8 \mathrm{bp})$ and generally A- or T-rich regions were not cut by DNase I at a detectable level and could therefore not be assayed for binding. Some $f t z-l a c Z$ fusion gene deletion end points are indicated.

sion directed by this element were localized to a 385-bp region (positions 1117-1502). A proximal element directs fusion gene expression in seven stripes in the mesoderm and ectoderm. A 794-bp fragment containing the proximal element was further dissected into two elements: Prox A directs expression in seven mesodermal stripes, whereas fusion genes containing only Prox B were not detectably expressed during embryogenesis. However, Prox B is necessary in conjunction with Prox A to direct expression detectable in the ectoderm. Thus, the proximal element identified in this study contains at least two regulatory regions that appear to interact. The resolution of the analysis presented here does not allow us to distinguish between the existence of two completely independent sequence elements-one utilized in the mesoderm and one in the ectoderm - and a more complex situation in which a shared regulatory element (now localized to Prox A) is utilized in both germ layers in combination with regionally restricted regulatory elements that are separable.
Both the distal and proximal elements identified in this study function in an orientation-independent fashion when linked to a heterologous promoter (fusion genes Rev 5'B, Rev 2043, and Rev 2023; data not shown). In addition, the deletion analysis effectively tests the distance dependence of these elements. The $3^{\prime}$ deletion series and construct IntA place the distal element progressively closer to the promoter without having any apparent effect on expression. In fusion gene IntB, Prox A is moved $\sim 200$ bp closer to the promoter without an apparent effect on mesodermal expression, and the distance effect for ectoderm expression of the proximal element is tested by reverse-orientation fusion genes Rev 5'B and Rev 2043. Thus, within the resolution of this analysis, the spacing between the individual regulatory elements and the transcription start site have no effect on expression. Furthermore, each element directs a spatially and temporally restricted pattern of gene expression when linked to a heterologous promoter. These observations indicate that both distal and proximal ele- 
Figure 10. The $f t z$ upstream element contains multiple regulatory units. $(A)$ The regulatory elements in the upstream element are summarized. The PS 4 activator is located between positions 1 and 413 of the upstream element. Sequences necessary (positions 1117-1502) and sufficient (positions 331-1502) for distal enhancer function are indicated. Prox A and Prox B elements (positions 1780-2363 and 2363-2574) in the proximal enhancer are also indicated (see text for details). $(B)$ A model for $f t z$ autoregulation. After general activation of $f t z$ transcription in the embryo, stripes are formed via repression of active transcription in the interstripe regions (Weir and Komberg 1985; Edgar et al. 1986). Although the initiation of transcription may be mediated by cooperative interactions between the zebra element and the upstream element, interstripe repression appears to be directed by sets of sequences in the zebra element that have been identified by Dearolf et al. (1989). When sufficient levels of $f t z$ protein (f) are synthesized in the stripes, the protein becomes available to interact with sequences in the upstream element, initiating an autoregulatory feedback loop that maintains and increases levels of transcription in the stripes. $f t z$ protein and ectoderm- or mesoderm-specific transcription factors, e and $m$, respectively, interact with sequences in the proximal and distal enhancers, as indicated. In neural precursor cells, one or more unidentified transcription factor(s) $n$ interacts with sequences in the neurogenic element to direct specific transcription. Although $f t z$ protein is synthesized, it cannot stimulate transcription via its potential binding sites in the upstream element enhancers in the absence of $\mathrm{e}$ and $\mathrm{m}$. Autoregulation serves to maintain $\mathrm{ftz}$ transcription in the stripes and may also be involved in generating the observed anterior-posterior concentration gradient of $f t z$ within each stripe (Lawrence et al. 1987; Lawrence and Johnston 1989).

ments function as developmentally regulated enhancers in Drosophila, which have the properties attributed to cell type-specific enhancers (Atchison 1988).

The identification of two independent regulatory elements that are active in the mesoderm suggests that one of these elements might be redundant in the context of the endogenous $f t z$ gene. However, the observation that fusion genes lacking the distal enhancer are expressed more weakly in both germ layers than those containing the full-length upstream element (Fig. 4) suggests that the distal enhancer may also be required to increase levels of expression in the ectoderm. In addition, both the significance and complexity of the proximal and distal enhancers are underscored by the observation that the region necessary for activity of the distal enhancer corresponds to the portion of $f t z 5^{\prime}$-flanking sequence that is most highly conserved between $D$. melanogaster and $D$. hydei and that long stretches of sequences in the proximal enhancer are exactly conserved in D. melanogaster, D. hydei, and D. virilis (Maier 1989; P. Baumgartner and W.J. Gehring, unpubl.).

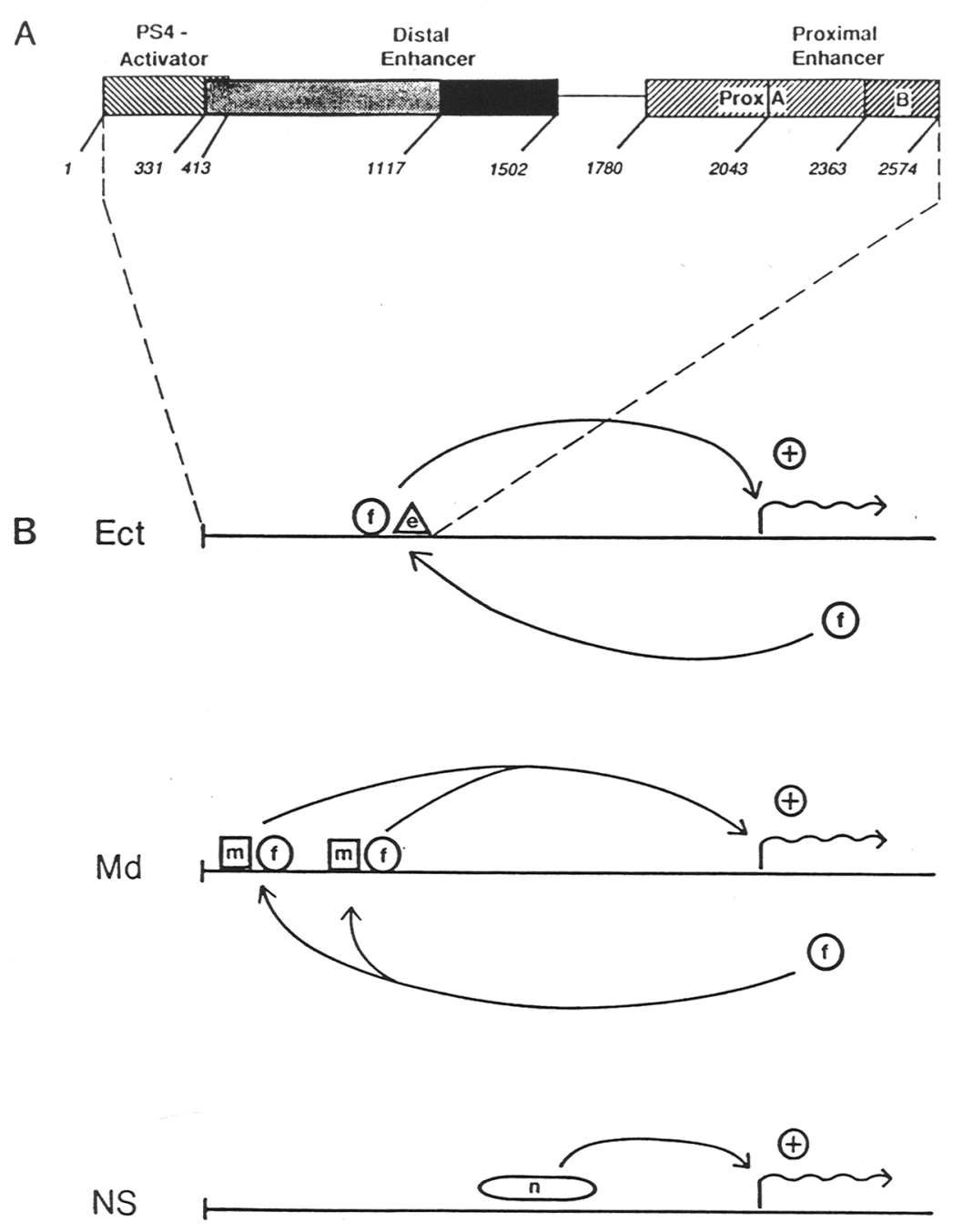

PS 4-specific activator is functionally separable from the upstream element enhancers

As shown in Figure 6, the $5^{\prime} 413$ bp of the upstream element contains sequences that direct fusion gene expression in a single stripe in the primordia of PS 4 in an orientation-dependent fashion (PS 4 activator, Fig. 10A). We suggest that this PS 4-specific regulatory element is not involved in the regulation of the endogenous $\mathrm{ftz}$ pattern, for the following reasons. First, although the single stripe of $\beta$-galactosidase activity overlaps with the region of the second $f t z$ stripe, the stripe is detectable earlier and at higher levels than the upstream element-directed seven $f t z$-like stripes. Thus, there is a regional overlap but neither a precise temporal nor quantitative correspondence between the patterns. Second, the genetic regulation of this element differs from that of the upstream element enhancers: The PS 4-specific activator is not a target for autoregulation (Fig. 7) and may be more directly regulated by gap genes (Hiromi and Gehring 1987; Y. Hiromi, pers. comm.|. Finally, the PS 
4-specific activator appears to be physically separate from the upstream element enhancers. Interestingly, in a parallel study, a nuclear scaffold attachment region (SAR) was identified in the ftz upstream element just $3^{\prime}$ of the PS 4-specific activator, in a region that is suggested to correspond to the $5^{\prime}$ end of the $f t z$ gene (B. Amati, L. Pick, T. LaRoche, and S. Gasser, in prep.).

If the PS 4-specific activator is not part of the ftz gene, what, then, is it? As pointed out previously, the PS 4specific expression resembles that of the Antennapedia gene (Antp), although it is not the result of trans-activation by the Antp product (Hiromi and Gehring 1987). The $f t z$ gene is located in the Antp complex (ANT-C), between the homeotic genes Sex combs reduced (Scr) and Antp (Scott et al. 1983; Kuroiwa et al. 1985). In D. melanogaster, $S c r$ and $f t z$ are transcribed in opposite orientations (Le Motte et al. 1989). In $D$. hydei the $f t z$ gene, including the upstream element, is highly conserved, and the orientation of $f t z$ with respect to $S c r$ is reversed, that is, the $3^{\prime}$ end of $f t z$ lies closer to $S c r$, presumably placing the $5^{\prime}$ end of $f t z$ closer to Antp (D. Maier, pers. comm). If the chromosomal configuration in $D$. hydei represents the ancestral organization of the ANT-C, then an inversion would have taken place since the divergence of $D$. melanogaster and $D$. hydei. An intriguing possibility is that part of an Antp regulatory region that directed Antp expression in PS 4 was included in the inversion. These Antp regulatory sequences would then remain upstream of the $f t z$ gene in $D$. melanogaster as an evolutionary relic. Such an inversion event would also explain the curious observation that $S c r$ mutations are located on both sides of the $\mathrm{ftz}$ gene (Scott et al. 1983; Seeger and Kaufman 1987) and predicts that these mutations would map within the breakpoint of the inversion such that the affected $S c r$ sequences would be located between the $f t z$ and $S c r$ transcription units in $D$. hydei.

\section{Purified $\mathrm{ftz}$ homeo domain interacts with the upstream element in vitro}

The expression of enhancer-lacZ fusion genes in seven $f t z$-like stripes is decreased to undetectable levels in $f t z$ mutants, indicating that wild-type $\mathrm{ftz}$ product is necessary for fusion gene expression (see Fig. 7 and below); however, these genetic experiments do not address questions regarding the mechanism of $f t z$ action in mediating this effect. The $f t z$ protein contains a homeo domain (McGinnis et al. 1984; Scott and Weiner 1984), binds to specific DNA sequences in vitro (Desplan et al. 1988; Laughon et al. 1988; Müller et al. 1988), and can stimulate transcription in yeast (Fitzpatrick and Ingles 1989) and in cell culture (Jaynes and O'Farrell 1988; Han et al. 1989; Winslow et al. 1989). These properties of the protein suggest that it could act directly to regulate the transcription of its own gene.

As a first step toward testing this model of direct autoregulation, we asked whether purified $f t z$ protein or $f t z$ homeo domain can interact with enhancer DNA sequences in vitro. We have found that $f t z$ homeo domain interacts with a large number of sites in the upstream element (Figs. 8 and 9). Both the distal and the proximal enhancers contain a single high-affinity binding site, as well as additional medium- and low-affinity sites. Comparison of all the footprinted regions does not allow us to identify a consensus sequence for all three classes of binding sites. Both of the high-affinity sites contain a GCAATTA sequence element, suggesting that this motif might be partly responsible for the high affinity of these sites. Although some of the medium-affinity sites do contain variations of the GCAATTA motif, others show very little sequence similarity to the high-affinity sites. In the case of the homeo domain-containing Oct-1 protein (also called OTF-1, OBP100, or NFIII; see Sturm and Herr 1988), very dissimilar DNA sequence elements are recognized in vitro, with only slightly different affinities (Baumruker et al. 1988).

The identification of a large number of $f t z$ homeo domain-binding sites in the upstream enhancers was somewhat surprising. Although it is possible that the clustering of binding sites throughout the upstream element has some functional significance, the relatively low selectivity of homeo domain-containing proteins for their DNA target sites suggests that a large number of potential binding sites may be present throughout the entire genome (see also Desplan et al. 1985). We suggest that in vitro DNA-binding studies such as the one presented here identify the total range of sites with which a given homeo domain-containing protein can potentially interact. Mutational analysis of various binding sites should now allow us to ask which of these binding sites are required for $\mathrm{ftz}$ responsiveness and to determine whether or not $f t z$ protein interacts directly with these DNA sequences in vivo.

\section{Model for germ layer-restricted upstream element autoregulation}

Expression of fusion genes containing either the fulllength upstream element or the independent $f t z$ regulatory elements is dependent on the presence of a wildtype $f t z$ gene in transformant embryos (Fig. 7; Hiromi and Gehring 1987). That this observed autoregulation is a property of the individual enhancers rather than being mediated by a single region within an intact upstream element supports the conclusion from the deletion analysis that the enhancers are independent functional units. Although enhancer-fusion gene expression is decreased to undetectable levels in $\mathrm{ftz}$ mutant embryos, it is broadened in $h$ mutant embryos in which the endogenous $f t z$ RNA and protein distribution is expanded. However, even when $f t z$ product is ectopically expressed in $h$ mutants, the germ layer restriction of the regulatory elements appears to be retained. This observation, along with the restricted expression of individual fusion genes, indicates that sequence elements that share the property of being $f t z$ responsive are differentially utilized in the ectoderm and mesoderm. In addition, these DNA sequence elements are apparently unable to respond to $f t z$ protein present in specific neural precursor cells and in the hindgut (Caroll and Scott 1986; Krause et al. 1988), where upstream element-containing fusion genes are 
not detectably expressed (Hiromi and Gehring 1987; L. Pick et al., unpubl.). These observations suggest that although $f t z$ product is required for enhancer activity, it alone is not sufficient to direct enhancer-fusion gene expression. We propose that each enhancer requires the activity of at least one other factor in addition to $f t z$ that determines its specificity.

A simple formulation of this model, as summarized in Figure $10 \mathrm{~B}$, is that transcriptional specificity is achieved by the interactions between $f t z$ protein and germ layerspecific factors, which, together, activate transcription via interactions with specific DNA sequences in the distal and proximal enhancers. In ectodermal cells and/or precursors, $f t z$ protein and an ectoderm-specific transcription factor (e) interact with sequences in the proximal enhancer; in mesodermal cells and/or precursors, a mesoderm-specific transcription factor $(\mathrm{m})$ and $f t z$ protein interact with sites in the distal and proximal enhancers. $f t z$ protein may interact with only the single high-affinity binding site in each of the enhancers (in which case mesodermal and ectodermal cells would utilize the same $f t z$-binding site in the proximal enhancer) or it may interact with several sites, including the medium- or low-affinity binding sites in an additive fashion. However, preliminary results indicate that the single high-affinity site in the proximal enhancer can be deleted without any significant effect on expression (data not shown). In neural and hindgut precursor cells, neither e nor $\mathrm{m}$, nor an equivalent factor allows $\mathrm{ftz}$ protein to bind to and/or to activate transcription from the enhancers.

We postulate further that the putative germ layer-specific factors are present throughout each germ layer because ectopic expression of enhancer-fusion genes appears to be limited by the domains of endogenous $f t z$ expression (see Fig. 7). Although we have proposed that the factors limiting the specificity of $f t z$-dependent expression are other DNA-binding transcription factors, our data are equally consistent with them being soluble factors that alter the specificity of $f t z$ protein-DNA binding or its ability to activate transcription, either by protein-protein interactions with or post-translational modifications of the $f t z$ protein. In the latter case, specific modifications might allow $f t z$ protein to activate transcription via different sites in the upstream element in the mesoderm and in the ectoderm and could inhibit activation in the developing nervous system and hindgut.

The model presented here in which different combinations of trans-acting factors interact to determine transcriptional specificity is consistent with models derived from studies of viral enhancers (for reviews, see introductory section). In the case of the $f t z$ enhancers, the combinatorial interaction of the putative enhancerbinding factors with $f t z$ protein would ensure a regionalspecific restriction of $f t z$ gene expression. In addition, if the putative enhancer-binding factors were necessary to increase the selectivity of $f t z$ DNA binding, it would explain why such a large number of DNA-binding sites have been found by us and others in in vitro experiments using single homeo domain-containing proteins. Such a model would also help to explain how homeo domaincontaining proteins that are expressed in overlapping spatial domains and that bind to overlapping sets of DNA sequences themselves (see Desplan et al. 1988; Hoey and Levine 1988; Laughton et al. 1988; Müller et al. 1988), could regulate specific gene expression in a controlled fashion during development. Finally, this model is also supported by experiments carried out with homeo domain-containing proteins in yeast. Mat $\alpha 2$ protein has been shown to bind DNA via cooperative interactions with a general transcription factor (Keheler et al. 1988), and Matal protein can modulate the specificity of Mat $\alpha 2$ DNA binding, thereby changing its gene regulatory function (Goutte and Johnson 1988). The challenge for the future will be to identify the transcription factors that interact with $\mathrm{ftz}$ protein.

\section{Experimental procedures}

\section{Construction of lacZ fusion genes}

Sequential deletions from either the $5^{\prime}$ or $3^{\prime}$ end of the $f t z$ upstream element were generated as follows. An XbaI fragment derived from plasmid pK $\Delta$ S-1 (L. Pick, unpubl.), containing the 2574-bp upstream element (Hiromi and Gehring 1987; Harrison and Travers 1988), was inserted in either orientation into the $X b a I$ site of a modified Bluescript $\mathrm{M}^{+} 3^{+}$vector $(\mathrm{pBKmOX}-\mathrm{H}$ and $\mathrm{pBKmOX}-\mathrm{T})$. This Bluescript vector contained a 1.3-kb Pst fragment encoding kanamycin resistance subcloned into the unique $X m n I$ site in the ampicillin-resistance gene, thereby inactivating the latter (M. Müller, unpubl.). This plasmid, pBKm, was further modified to create an Xhol, KpnI cassette by the insertion of a double-stranded oligonucleotide containing these two restriction endonuclease sites and $S a c I$ ends into the unique SacI site in the polylinker (plasmid pBKmO). The oligonucleotides used had the sequence 5 '-CCTCGAGGGTACCGAGCT-3' ; 3 '-TCGAGGAGCTCCCATGGC-5'.

Deletions in both orientations were then generated by BstXI and NotI digestion of $\mathrm{pBKmOX}-\mathrm{H}$ and $\mathrm{pBKmOX}-\mathrm{T}$, followed by exonuclease III/mung bean nuclease treatment, as recommended by the manufacturer (Stratagene Cloning Systems). Protruding ends were filled in using DNA polymerase I large fragment, and the plasmids were religated. Deletion end points were determined by dideoxynucleotide sequencing (Sanger et al. 1977) or by chemical cleavage of isolated DNA fragments (Maxam and Gilbert 1977). Fragments of interest were subsequently released from the vector by digestion with KpnI, gelisolated, and inserted in either orientation into the unique KpnI site of the Camegie 20-derived vector HZ50PL (Hiromi and Gehring 1987). The region cloned into HZ50PL included $\sim 80$ bp of polylinker sequence between the $f t z$ DNA and the $h s p 70$ basal promoter. Examination of the expression patterns of $\beta$-galactosidase in transformant embryos, carrying the full-length upstream element and several of the deletion derivatives, revealed that expression was significantly weaker than expected ( 10-20 times when compared to UPHZ50H). The full-length upstream element fragment was then reisolated from this fusion gene by use of $X b a I$ and removal of the Bluescript polylinker sequences. Insertion of this fragment into the unique $X b a I$ site of HZ50PL restored quantitative levels of expression. Thus, the use of the large Bluescript polylinker appears to have led to suppression of fusion gene expression. We have not investigated the causes of this phenomenon further; however, in our experience, low levels of $\beta$-galactosidase activity may be 
reduced to undetectable levels, leading to misinterpretation of a given pattern (data not shown). We note that repression of expression of fusion genes by vector sequences has also been observed for mouse transgenes (Chada et al. 1985).

To avoid interference by Bluescript polylinker sequences, all $5^{\prime}$ deletion fragments were excised from HZ50PL with Xbal (made possible by the $3^{\prime} X b a$ I site remaining from the initial cloning into $\mathrm{pBKmO}$ and the $X b a I$ site lying $5^{\prime}$ to the KpnI site in HZ50PL) and recloned into the XbaI site of HZ50PL. Again, all fusion genes containing $X b a I$ fragments were expressed at higher levels than those containing the corresponding KpnI fragments. The $5^{\prime}$ deletion constructs presented here include only those examined after recloning into the $\mathrm{XbaI}$ site. Although the $3^{\prime}$ deletion constructs did not contain large amounts of the Bluescript polylinker, some new 3' deletion fusion genes were created by using restriction endonucleases. Fragments were excised from the parental plasmid $\mathrm{pBKmOX}-\mathrm{H}$ with $\mathrm{XbaI}$ and an appropriate restriction endonuclease. The $\mathrm{XbaI}$ end of each fragment was ligated into the $X b a I$ site of HZ50PL, ends were filled in with the large fragment of DNA polymerase I, and the plasmids were then recircularized with T4 DNA ligase. No apparent difference in expression was seen between $3^{\prime}$ deletion fusion genes inserted into the $K p n I$ and $X b a I$ sites.

For plasmids IntA and $5^{\prime} \mathrm{D}, \mathrm{XbaI}$ fragments containing upstream element sequences were isolated from the clones pryFGHR1 or pryFGHRX (kindly provided by Dr. Y. Hiromi) and inserted directly into the XbaI site of HZ50PL. Plasmid IntB was generated by EcoRV digestion and $5^{\prime} \mathrm{F}$ by $\mathrm{HpaI}$ digestion of an isolated $X b a I$ fragment from the plasmid $5^{\prime} E$. Fragments were inserted into the Xbal site of HZ50PL, as described above. All cloning steps were carried out according to standard procedures (Maniatis et al. 1982).

\section{Germ-line transformation and analysis of expression patterns}

P-element-mediated transformation and establishment of balanced or homozygous transformant stocks and detection of $\beta$ galactosidase activity using the chromogenic substrate 5bromo-4-chloro-3-indolyl- $\beta$-D-galactopyranoside (X-gal) was as described previously (Hiromi and Gehring 1987). Expression patterns were examined in multiple independent lines for each construct (see Fig. 1). Striped patterns of expression presented here were seen in all lines examined for any given construct. We observed considerable variation in the levels of $\beta$-galactosidase activity between different independent lines transformed with the same construct, although the patterns were qualitatively the same in all lines. As has been seen for other $\mathrm{ftz}-\mathrm{lacZ}$ fusion genes (Hiromi et al. 1985; Dearolf et al. 1989), staining anterior to the cephalic furrow was observed in some cases. For examination of thin sections, staged embryos were stained for $\beta$-galactosidase activity according to Bellen et al. (1989) or Hiromi and Gehring (1987) and embedded in Tissue-Tek O.C.T. compound (Miles Scientific). Cryostat sections (13 $\mu \mathrm{m})$ were prepared as described by Hafen and Levine (1986).

\section{Analysis of expression in mutant embryos}

The mutant alleles used were $f t z 9 H 34$ (Jürgens et al. 1984) or $h$ $5 H 07$ or $h I L 79 K$ (Ingham et al. 1985). Mutants (linked to the third chromosome) were crossed to transformant flies carrying a ftz enhancer transgene on the second chromosome. Heterozygous flies for both the mutation and the fusion gene were crossed to each other, and embryos were stained for $\beta$-galactosidase activity. Homozygous mutant embryos were identified by characteristic morphological changes observed at later stages of embryogenesis or by double staining with antibodies against engrailed protein (Patel et al. 1989). The analysis of wild-type and $h^{-}$mutant embryos revealed that the anterior boundaries of even-numbered engrailed stripes correspond to the anterior boundaries of fusion gene stripes (data not shown). As the anterior border of the mature $f t z$ stripes also coincides with the anterior border of engrailed stripes (Lawrence and Johnston 1989), fusion gene expression seems to be confined (in both wild-type and $h^{-}$mutant embryos) to the region where $f t z$ protein is expressed.

\section{DNase I protection assays}

DNA fragments used for footprint analysis were subcloned into a Bluescript $\mathrm{M} 13^{+}$vector, digested with an appropriate restriction enzyme, and either 5 '-end-labeled with $\left[\gamma^{-32} \mathrm{P}\right] \mathrm{ATP}$ and T4 polynucleotide kinase or $3^{\prime}$-end-labeled with $[\alpha-32$ P]dATP and the large fragment of DNA polymerase I (Maniatis et al. 1982). Following cleavage with a second restriction enzyme, DNA fragments were purified after excision from native polyacrylamide gels. Binding reactions $(100 \mu \mathrm{l})$ containing $20 \mathrm{mM}$ Tris$\mathrm{HCl}$ (pH 7.6), $75 \mathrm{~mm} \mathrm{KCl} 5 \mu \mathrm{g} \mathrm{BSA}, 1 \mathrm{~mm}$ DTT, $10 \%$ glycerol, ${ }^{32}$ P-labeled DNA, and varying amounts of purified $f t z$ homeo domain or full-length $\mathrm{ftz}$ protein were incubated for $60 \mathrm{~min}$ on ice. $\mathrm{CaCl}_{2}, \mathrm{MgCl}_{2}$, and poly[d(I-C)] were added to final concentrations of $2.5 \mathrm{~mm}, 5 \mathrm{~mm}$, and $10 \mu \mathrm{g} / \mathrm{ml}$, respectively, and reaction mixtures were incubated with DNase $\mathrm{I}\{0.5-1.0 \mu \mathrm{g} / \mathrm{ml})$ for $8 \mathrm{~min}$ on ice. Reactions were stopped by the addition of $100 \mu \mathrm{l}$ of $10 \mathrm{~mm}$ Tris- $\mathrm{HCl}(\mathrm{pH} 7.6)$, containing $0.4 \%$ SDS and $20 \mathrm{~mm}$ EDTA. Reaction mixtures were heated at $65^{\circ} \mathrm{C}$ for $15 \mathrm{~min}$, and the samples were extracted with equal volumes of phenol/chloroform (1:1) and chloroform. Following ethanol precipitation, DNase I cleavage products were separated on $8.3 \mathrm{M}$ urea $/ 6 \%$ polyacrylamide gels with $G+A$ reaction cleavage reactions as marker (Maxam and Gilbert 1977).

The full-length $\mathrm{ftz}$ protein used in the footprint assays was synthesized in $E$. coli and purified to near homogeneity (Krause et al. 1988). The $\mathrm{ftz}$ homeo domain was synthesized in $E$. coll BL21 (DE3) lysogen (Studier and Moffat 1986) and purified to homogeneity (M. Müller and W.J. Gehring, unpubl.). Protein concentrations were determined by using the Bio-Rad dye reagent according to the method of Bradford (1976). The purified $f t z$ homeo domain peptide contains two additional amino acids at the amino terminus as a result of the cloning and overexpression procedure and is extended by eight naturally occurring amino acids at the carboxyl terminus, resulting in a 70 -aminoacid peptide.

\section{Acknowledgments}

We are grateful to Yash Hiromi for providing plasmid DNAs and fly strains and for his helpful suggestions throughout the course of this work. We thank Martin Müller for generously providing purified $f t z$ homeo domain for the footprinting experiments, Dieter Maier for sharing unpublished information, Paul Baumgartner for sequencing some of the deletion end points, and Henry Krause for providing full-length $\mathrm{ftz}$ protein. L.P. thanks Thomas Gutjahr for many invaluable discussions and suggestion and the members of the Gehring lab for advice and encouragement. Many thanks go to Clive Wilson, Anette Preiss, Anthony Percival-Smith, and Yash Hiromi for their comments on the manuscript. This work was supported by Amersham International, the Kantons Basel, and by a grant to W.J.G. from Sandoz. T.S.G. was supported by a Professional Staff Congress-City University of New York grant (6-66159) and by a Research Centers in Minority Institutions Award 
(RCMI, RR-03037) from the Division of Research Resources, National Institutes of Health. L.P. was supported by a Damon Runyon-Walter Winchell Cancer Fund Fellowship (DRG-912).

The publication costs of this article were defrayed in part by payment of page charges. This article must therefore be hereby marked "advertisement" in accordance with 18 USC section 1734 solely to indicate this fact.

\section{References}

Akam, M. 1987. The molecular basis for metameric pattern in Drosophila embryo. Development 101: 1-22.

Atchison, M.L. 1988. Enhancers: Mechanisms of action and cell specificity. Annu. Rev. Cell Biol. 4: 127-153.

Baumruker, T., R. Sturm, and W. Herr. 1988. OBP100 binds remarkably degenerate octamer motifs through specific interactions with flanking sequences. Genes Dev. 2: 1400-1413.

Bellen, H.J., C.J. O'Kane, C. Wilson, U. Grossniklaus, R. Kurth Pearson, and W.J. Gehring. 1989. P-element-mediated enhancer detection: A versatile method to study development in Drosophila. Genes Dev. 3: 1288-1300.

Bienz, M., G. Saari, G. Tremml, J. Müller, B. Züst, and P.A. Lawrence. 1988. Differential regulation of Ultrabithorax in two germ layers of Drosophila. Cell 53: 567-576.

Boulet, A.M. and M.P. Scott. 1988. Control elements of the P2 promoter of the Antennapedia gene. Genes Dev. 2: 16001614.

Bradford, M.M. 1976. A rapid and sensitive method for the quantification of microgram quantities of protein utilizing the principle of protein-dye binding. Anal. Biochem. 72: $248-254$

Carroll, S.B. and M.P. Scott. 1985. Localization of the fushi tarazu protein during Drosophila embryogenesis. Cell 43: 47-57.

1986. Zygotically active genes that affect the spatial expression of the fushi tarazu segmentation gene during early Drosophila embryogenesis. Cell 45: 113-126.

Chada, K., J. Magram, K. Raphael, G. Radice, E. Lacy, and F. Costantini. 1985. Specific expression of a foreign $\beta$-globin gene in erythroid cells of transgenic mice. Nature 314: 377380.

Dearolf, C.R., J. Topol, and C.S Parker. 1989. Transcriptional control of Drosophila fushi tarazu zebra stripe expression. Genes Dev. 3: 384-398.

Desplan, C., J. Theis, and P.H. O'Farrell. 1985. The Drosophila developmental gene, engrailed, encodes a sequence-specific DNA binding activity. Nature 318: 630-635.

-1988. The sequence specificity of homeo domain-DNA interaction. Cell 54: 1081-1090.

Edgar, B.A., M.P. Weir, G. Schubiger, and T. Kornberg. 1986. Repression and turnover pattern fushi tarazu RNA in the early Drosophila embryo. Cell 47: 747-754.

Fitzpatrick, V.D. and C.J. Ingles. 1989. The Drosophila fushi tarazu polypeptide is a DNA-binding transcriptional activator in yeast cells. Nature 337: 666-668.

Garabedian, M.J., B.M. Shepherd, and P.C. Wensink. 1986. A tissue-specific transcription enhancer from the Drosophila yolk protein 1 gene. Cell 45: 859-867.

Gergen, J.P., D. Coulter, and E. Wieschaus. 1986. Segmental pattern and blastoderm cell identities. In Gametogenesis and the early embryo, (ed. S. Subtelny), pp. 195-220. Alan R. Liss, New York.

Goto, T., P. Macdonald, and T. Maniatis. 1989. Early and late periodic patterns of even-skipped expression are controlled by distinct regulatory elements that respond to different spatial cues. Cell 57: 413-422.
Goutte, C. and A.D. Johnson. 1988. al protein alters the DNA binding specificity of $\alpha 2$ repressor. Cell 52: 875-882.

Hafen, E. and M. Levine. 1986. The localization of RNAs in Drosophila tissue sections by in situ hybridization. In Drosophila: A practical approach (ed. D.B. Roberts), pp. 138-158. IRL Press.

Hafen, E. and M. Levine. 1986. The localization of RNAs in Drosophila tissue sections by in situ hybridization. In Drosophila: A practical approach (ed. D.B. Roberts), pp. 138-158. IRL Press, Oxford.

Hammer, R.E., R. Krumlauf, S.A. Camper, R.L. Brinster, and S.M. Tilghman. 1987. Diversity of alpha-fetoprotein gene expression in mice is generated by a combination of separate enhancer elements. Science 235: 53-58.

Han, K., M.S. Levine, and J.L. Manley. 1989. Synergistic activation and repression of transcription by Drosophila homeobox proteins. Cell 56: $573-583$.

Harding, K., T. Hoey, R. Warrior, and M. Levine. 1989. Autoregulatory and gap gene response elements of the evenskipped promoter of Drosophila. EMBO J. 8: 1205-1212.

Harrison, S.D. and A.A. Travers. 1988. Identification of the binding sites for potential regulatory proteins in the upstream enhancer element of the Drosophila fushi tarazu gene. Nucleic Acids Res. 16: 11403-11416.

Hiromi, Y. and W.J. Gehring. 1987. Regulation and function of the Drosophila segmentation gene fushi tarazu. Cell 50: $963-974$.

Hiromi, Y., A. Kuroiwa, and W.J. Gehring. 1985. Control elements of the Drosophila segmentation gene fushi tarazu. Cell 43: 603-613.

Hoey, T. and M. Levine. 1988. Divergent homeo box proteins recognize similar DNA sequences in Drosophila. Nature 332: $858-861$.

Howard, K. and P. Ingham. 1986. Regulatory interactions between the segmentation genes fushi tarazu, hairy, and engrailed in the Drosophila blastoderm. Cell 44: 949-957.

Howard, K., P. Ingham, and C. Rushlow. 1988. Region-specific alleles of the Drosophila segmentation gene hairy. Genes Dev. 2: 1037-1046.

Ingham, P.W. 1988. The molecular genetics of embryonic pattern formation in Drosophila. Nature 335: 25-33.

Ingham, P.W., S.M. Pinchin, K.R. Howard, and D. Ish-Horowicz. 1985. Genetic analysis of the hairy locus in Drosophila melanogaster. Genetics 111: 463-486.

Ish-Horowicz, D. and S.M. Pinchin. 1987. Pattern abnormalities induced by ectopic expression of the Drosophila gene hairy are associated with repression of $\mathrm{ftz}$ transcription. Cell 51: 405-415.

Jaynes, J.B. and P.H. O'Farrell. 1988. Activation and repression of transcription by homeodomain-containing proteins that bind a common site. Nature 336: 744-749.

Johnson, W.A., C.A. McCormick, S.J. Bray, and J. Hirsch. 1989. A neuron-specific enhancer of the Drosophila dopa decarboxylase gene. Genes Dev. 3: 676-686.

Jürgens, G., E. Wieschaus, C. Nüsslein-Volhard, and H. Kluding. 1984. Mutations affecting the pattern of the larval cuticle in Drosophila melanogaster. II. Zygotic loci on the third chromosome. Wilhelm Roux's Arch. Dev. Biol. 193: $283-295$.

Keheler, C.A., C. Goutte, and A.D. Johnson. 1988. The yeast cell-type-specific repressor $\alpha 2$ acts cooperatively with a non-cell-type-specific protein. Cell 53: 927-936.

Krause, H.M., R. Klemenz, and W.J. Gehring. 1988. Expression, modification and localization of the fushi tarazu protein in Drosophila embryos. Genes Dev. 2: 1021-1036.

Kuroiwa, A., E. Hafen, and W.J. Gehring. 1984. Cloning and 
transcriptional analysis of the segmentation gene fushi tarazu of Drosophila. Cell 37: 825-831.

Kuroiwa, A., U. Kloter, P. Baumgartner, and W.J. Gehring. 1985. Cloning of the homeotic Sex combs reduced gene in Drosophila and in situ localization of its transcripts. $E M B O F$. 4: 3757-3764.

Laughon, A. and M.P. Scott. 1984. Sequence of a Drosophila segmentation gene: Protein structure homology with DNAbinding proteins. Nature 310: 25-31.

Laughon, A., W. Howell, and M.P. Scott. 1988. The interaction of proteins encoded by Drosophila homeotic and segmentation genes with specific DNA sequences. Development 104: $75-83$.

Lawrence, P.A. 1987. Pair-rule genes: Do they paint stripes or draw lines? Cell 51: 879-880.

Lawrence, P.A. and P. Johnston. 1989. Pattern formation in the Drosophila embryo: Allocation of cells to parasegments by even-skipped and fushi tarazu. Development 105: 761-767.

Lawrence, P.A., P. Johnston, P. Macdonald, and G. Struhl. 1987. Borders of parasegments in Drosophila embryos are delimited by the fushi tarazu and even-skipped genes. Nature 328: 440-442.

LeMotte, P.K., A. Kuroiwa, L.I. Fessler, and W.J. Gehring. 1989. The homeotic gene Sex combs reduced of Drosophila: Gene structure and embryonic expression. EMBO I. 8: 219-227.

Levine, M.S. and C.J. Wedeen. 1985. Homeotic gene expression in Drosophila. Trends Neurosci. 8: 239-245.

Lewis, E.B. 1978. A gene complex controlling segmentation in Drosophila. Nature 276: 565-570.

Logan, S.K., M.J. Garabedian, and P.C. Wensink. 1989. DNA regions that regulate the ovarian transcriptional specificity of Drosophila yolk protein genes. Genes Dev. 3: 1453-1461.

Maier, D. 1989. Konservierung regulatorischer DNA-Sequenzen der Gene fushi tarazu und rosy in der Evolution von Drosophila. Ph.D. thesis, Eberhard-Karls-Universität Tübingen.

Maniatis, T., E.F. Fritsch, and S. Sambrook. 1982. Molecular cloning: A laboratory manual. Cold Spring Harbor Laboratory Press, Cold Spring Harbor, New York.

Maniatis, T., S. Goodbourn, and J.A. Fischer. 1987. Regulation of inducible and tissue-specific gene expression. Science 236: $1237-1245$.

Martinez-Arias, A. and P.A. Lawrence. 1985. Parasegments and compartments in the Drosophila embryo. Nature 313: 639642.

Maxam, A.M. and W. Gilbert. 1977. A new method for sequencing DNA. Proc. Natl. Acad. Sci. 74: 560-564.

McGinnis, W., M.S. Levine, E. Hafen, A. Kuroiwa, and W.J. Gehring. 1984. A conserved DNA sequence in homeotic genes of the Drosophila Antennapedia and bithorax complexes. Nature 308: 428-433.

Mitchell, P.J. and R. Tjian. 1989. Transcriptional regulation in mammalian cells by sequence-specific DNA binding proteins. Science 245: 371-378.

Müller, M., M. Affolter, W. Leupin, G. Otting, K. Wüthrich, and W.J. Gehring. 1988. Isolation and sequence-specific DNA binding of the Antennapedia homeodomain. EMBO $J$. 7: 4299-4304.

Nüsslein-Volhard, C. and E. Wieschaus. 1980. Mutations affecting segment number and polarity in Drosophila. Nature 287: 795-801.

Nüsslein-Volhard, C., H.G. Frohnhöfer, and R. Lehmann. 1987. Determination of anteroposterior polarity in Drosophila. Science 238: 1675-1681.

Ondek, B., L. Gloss, and W. Herr. 1988. The SV40 enhancer contains two distinct levels of organization. Nature
333: 40-45.

Patel, N.H., E. Martin-Blanco, K.G. Coleman, S.J. Poole, M.C. Ellis, T.B. Kornberg, and C.S. Goodman. 1989. Expression of engrailed proteins in arthropods, annelids, and chordates. Cell 58: 955-968.

Peifer, M., F. Karch, and W. Bender. 1987. The bithorax complex: Control of segmental identity. Genes Dev. 1: 891-898.

Pinkert, C.A., D.M. Orditz, R.L. Brinster, and R.D. Palmiter. 1987. An albumin enhancer located $10 \mathrm{~kb}$ upstream functions along with its promoter to direct efficient, liver-specific expression in transgenic mice. Genes Dev. 1: 268-276.

Posakony, J.W., J.A. Fischer, and T. Maniatis. 1985. Identification of DNA sequences required for the regulation of Drosophila alcohol dehydrogenase gene expression. Cold Spring Harbor Symp. Quant. Biol. 50: 515-520.

Rubin, G.M. and A.C. Spradling. 1982. Genetic transformation of Drosophila with transposable element vectors. Science 218: $348-353$.

Sanger, F., S. Nicklen, and A.R. Coulson. 1977. DNA sequencing with chain-terminating inhibitors. Proc. Natl. Acad. Sci. 74: 5463-5467.

Schirm, S., J. Jiricny, and W. Schaffner. 1987. The SV40 enhancer can be dissected into multiple segments, each with a different cell type specificity. Genes Dev. 1: 65-74.

Schneuwly, S., R. Klemenz, and W.J. Gehring. 1987. Redesigning the body plan of Drosophila by ectopic expression of the homeotic gene Antennapedia. Nature 235: 816-818.

Scott, M.P. and P.H. O'Farrell. 1986. Spatial programming of gene expression in early Drosophila embryogenesis. Annu. Rev. Cell Biol. 2: 49-80.

Scott, M.P. and A.J. Weiner. 1984. Structural relationships among genes that control development: Sequence homology between the Antennapedia, Ultrabithorax, and fushi tarazu loci of Drosophila. Proc. Natl. Acad. Sci. 81: 4115-4119.

Scott, M.P., A.J. Weiner, T.I. Hazelrigg, B.A. Polisky, V. Pirrotta, F. Scalenghe, and T.C. Kaufman. 1983. The molecular organization of the Antennapedia locus of Drosophila. Cell 35: 763-776.

Seeger, M.A. and T.C. Kaufman. 1987. Homeotic genes of the Antennapedia complex (ANT-C) and their molecular variability in the phylogeny of the Drosophilidae. In Development as an evolutionary process, (ed. R.A. Raff), pp. 179-202. Alan R. Liss, New York.

Serfling, E., M. Jasin, and W. Schaffner. 1985. Enhancers and eucaryotic gene transcription. Trends Genet. 1: 224-230.

Spradling, A.C. and G.M. Rubin. 1982. Transposition of cloned P elements into Drosophila germ line chromosomes. Science 218: $341-347$.

Struhl, G. 1985. Near-reciprocal phenotypes caused by inactivation or indiscriminate expression of the Drosophila segmentation gene $f t z$. Nature 318: 677-680.

Studier, F.W. and B.A. Moffat. 1986. Use of bacteriophage T7 RNA polymerase to direct selective high-level expression of cloned genes. J. Mol. Biol. 189: 113-130.

Sturm, R.A. and W. Herr. 1988. The POU domain is a bipartite DNA-binding structure. Nature 336: 601-604.

Weir, M.P. and T. Kornberg. 1985. Patterns of engrailed and fushi tarazu transcripts reveal novel intermediate stages of Drosophila segmentation. Nature 318: 433-439.

Winslow, G.M., S. Hayashi, M. Krasnow, D.S. Hogness, and M.P. Scott. 1989. Transcriptional activation by the Antennapedia and fushi tarazu proteins in cultured Drosophila cells. Cell 57: 1017-1030. 


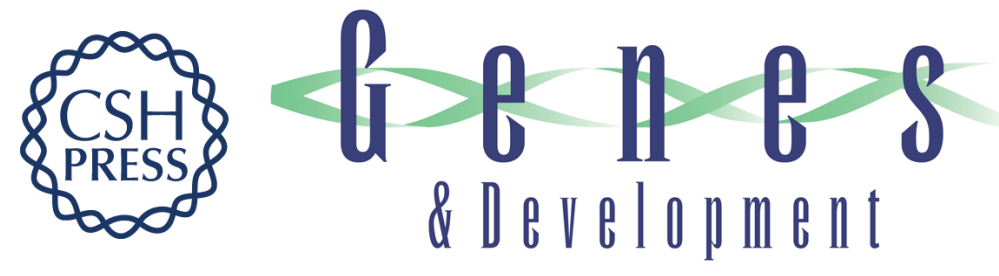

\section{Analysis of the ftz upstream element: germ layer-specific enhancers are independently autoregulated.}

L Pick, A Schier, M Affolter, et al.

Genes Dev. 1990, 4:

Access the most recent version at doi:10.1101/gad.4.7.1224

References This article cites 73 articles, 25 of which can be accessed free at: http://genesdev.cshlp.org/content/4/7/1224.full.html\#ref-list-1

License

Email Alerting

Service

Receive free email alerts when new articles cite this article - sign up in the box at the top right corner of the article or click here.

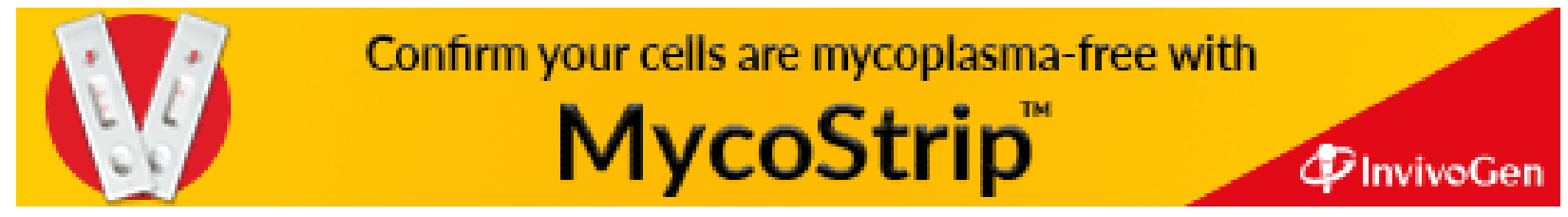

